\title{
VOLCANS: an objective, structured and reproducible method for identifying sets of analogue volcanoes
}

\author{
Pablo Tierz ${ }^{1,2}$ (I) Susan C. Loughlin ${ }^{1} \cdot$ Eliza S. Calder ${ }^{2}$ \\ Received: 23 February 2019 / Accepted: 8 November 2019 / Published online: 6 December 2019 \\ (C) The Author(s) 2019
}

\begin{abstract}
The definition of a suite of analogue volcanoes, or volcanoes that are considered to share enough characteristics as to be considered exchangeable to a certain extent, is becoming a key component of volcanic hazard assessment. This is particularly the case for volcanoes where data are lacking or scarce. Moreover, volcano comparisons have often been based on similarities and differences inferred through expert judgement and not necessarily informed by volcano characteristics from global datasets. These similarities can be based on a range of features, from very simplified (e.g. statrovolcanoes) to very specific (e.g. detailed eruption chronologies), and may be strongly influenced by the personal experience of individuals or teams conducting the analogue analysis. In this work, we present VOLCANS (VOLCano ANalogues Search) - an objective, structured and reproducible method to identify sets of analogue volcanoes from global volcanological databases. Five overarching criteria (tectonic setting, rock geochemistry, volcano morphology, eruption size and eruption style), and a structured combination of them, are used to quantify overall multi-criteria volcano analogy. This innovative method is complementary to expert-derived sets of analogue volcanoes and provides the user with full flexibility to weigh the criteria and identify analogue volcanoes applicable to varied purposes. Some results are illustrated for three volcanoes with diverse features and significant recent and/or ongoing eruptions: Kîlauea (USA), Fuego (Guatemala) and Sinabung (Indonesia). The identified analogue volcanoes correspond well with a priori analogue volcanoes derived from expert knowledge. In some cases, single-criterion searches may not be able to isolate a reduced set of analogue volcanoes but any multicriteria search can provide high degrees of granularity in the sets of analogue volcanoes obtained. Data quality and quantity can be important factors, especially for single-criterion searches and volcanoes with very scarce data (e.g. Sinabung). Nevertheless, the method gives stable results overall across multi-criteria searches of analogue volcanoes. Potential uses of VOLCANS range from quantitative volcanic hazard assessment to promoting fundamental understanding of volcanic processes.
\end{abstract}

Keywords Global volcanism · Global database · Volcano morphology · Volcanic hazard assessment · Scarce data · Objective analogue volcano

\section{Introduction}

Volcanoes are powerful manifestations of our geodynamic planet. Volcanic physico-chemical processes are extraordinarily

Editorial responsibility: C.E.Gregg

Electronic supplementary material The online version of this article (https://doi.org/10.1007/s00445-019-1336-3) contains supplementary material, which is available to authorized users.

Pablo Tierz

pablo@bgs.ac.uk

1 British Geological Survey, The Lyell Centre, Edinburgh, UK

2 School of Geosciences, University of Edinburgh, Edinburgh, UK complex and operate on spatial and temporal scales ranging over many orders of magnitude (Sigurdsson et al. 2015). Therefore, volcanic behaviour is truly challenging to understand and even more challenging to forecast. Volcano scientists worldwide are asked, on a daily basis, to collect, process and interpret varied types and sources of volcanological data (e.g. deposits of volcanic material, chemical compositions of volcanic minerals and rocks, seismic signals from volcano-tectonic earthquakes, ground deformation, gas emissions) for its use in forecasting the future short- and long-term evolution of a particular volcanic system (e.g. Newhall and Hoblitt 2002; Loughlin et al. 2015; Newhall et al. 2017). Some frequently active volcanoes may appear somehow predictable (e.g. Stromboli, Italy), due to the fact that they tend to behave as they have behaved in the past (e.g. Blackburn et al. 1976; Rosi 
et al. 2000; Taddeucci et al. 2015). Yet, this by no means excludes relatively rapid changes in behaviour towards less expected phenomena: e.g. paroxysmal activity at Stromboli (e.g. Bertagnini et al. 2003; Calvari et al. 2006; Aiuppa et al. 2010), of which the 3 July and 28 August 2019 explosions were a powerful reminder. Other frequently active volcanoes may show more complex behaviours, such as switching between open-conduit (i.e. magma is filling the conduit below the crater and feeds the eruption) and closed-conduit regimes (i.e. the conduit is plugged by a semi- or totally-crystallysed rock). Some volcanoes may erupt frequently enough that sufficient data can be collected to postulate qualitative or quantitative forecasting models of volcanic activity (e.g. Volcán de Colima, Mexico; Luhr and Carmichael 1990; De la CruzReyna 1993; Luhr et al. 2002). Volcanoes that erupt infrequently and/or have very few data available concerning past behaviour are more numerous: Loughlin et al. (2015) estimated that about $70 \%$ of the world's Holocene (last $\sim 12 \mathrm{kyr}$ ) volcanoes are very poorly studied. These volcanoes may show no eruptive signs for centuries and, therefore, go unnoticed by local populations but they may, in a matter of weeks to months, grow restless and produce energetic eruptions. For instance, Mount Pinatubo (Philippines), erupted in 1991 after approximately 500 years of repose, in what was the second largest eruption of the 20th century (Newhall and Punongbayan 1996). These poorly-studied, potentially dangerous volcanoes are one major reason why the volcanological community has sought to identify analogue volcanoes, which are volcanoes believed to share some commonalities in terms of their specific "type, magma composition, repose period, or any other characteristics of interest" (Newhall et al. 2017).

Volcano observatories and crisis-response teams worldwide, such as the Volcano Disaster Assistance Program of the United States Geological Survey (https:/volcanoes.usgs. gov/projects/VDAP/about.html), have been using analogue volcanoes to inform their volcanic hazard assessments over the last decades, which has helped protect communities living around active volcanoes in many countries around the world (Sandri et al. 2012; Ogburn et al. 2015; Newhall and Pallister 2015; Newhall et al. 2017). More broadly, analogue volcanoes have been identified for the purpose of classification (Hone et al. 2007) or, in general, to improve hazard assessments at different temporal and spatial scales (Marzocchi et al. 2004; Mastin et al. 2009; Sandri et al. 2012; Whelley et al. 2015). Table 1 contains a summary of previous studies on analogue volcanoes, the purpose of the analysis and the criteria that have been most commonly used to define sets of analogue volcanoes.

Volcano types are usually grouped according to classical stratovolcanoes (Sheldrake 2014) or calderas (Sobradelo et al. 2010; Acocella et al. 2015) but more detailed analyses of geomorphological features have also been proposed (Whelley et al. 2015). Geographic setting has been used to ensure homogeneity between sets of volcanoes (Bebbington 2014) and it sometimes corresponds well with broad classes of tectonic setting (Hone et al. 2007; Whelley et al. 2015). Similarity in magma composition is typically described by simple geochemical divisions (e.g. mafic/felsic or basalt/andesite/dacite/rhyolite, Hone et al. 2007; Mastin et al. 2009; Ogburn et al. 2015), but more elaborate schema may include rock affinity (e.g. tholeiitic/calc-alkaline/alkaline, Sobradelo et al. 2010). In terms of (explosive) eruption size and style, Volcanic Explosivity Index (VEI, Newhall and Self 1982) is a customary choice (Bebbington 2014; Ogburn et al. 2015) but a great variety of more-or-less specific metrics have been used. These include the following: repose period, open/ closed conduit, mass eruption rates, grain size distribution, lava-dome-growth durations and extrusion rates and generation of specific types of pyroclastic density currents (PDCs) (Marzocchi et al. 2004; Mastin et al. 2009; Sandri et al. 2012, 2014; Sheldrake 2014; Ogburn et al. 2015).

Classically, analogue volcanoes are identified by classifying volcanoes into isolated compartments or categories (e.g. andesitic stratovolcanoes that generate dome-collapse PDCs). At high levels of detail, the number of categories can be very large and volcanoes become seemingly unique (Cashman and Biggs 2014). Consequently, the identified sets of analogue volcanoes may be suited for a given specific problem but wider applicability of the methods and results is prevented. In addition, the common practice in choosing analogue volcanoes is almost purely based on the personal experience or knowledge of the hazard analyst or team. The selection of analogue volcanoes under such circumstances may be significantly biased by specific eruption behaviour patterns known from a handful of volcanoes rather than from global databases.

In this study, we develop an objective, structured and reproducible method for identifying sets of analogue volcanoes based on information from three global volcanological databases. We refer to this tool as VOLCANS (VOLCano ANalogues Search). Different criteria (tectonic setting, rock geochemistry, volcano morphology, etc.) are used to quantify either single-criterion or multi-criteria volcano analogy, which is interpreted as the inverse of a distance metric defined between any two volcanic systems in the databases. This distance metric is a proxy for dissimilarity and is calculated using normalised numerical variables, which provides a quantification of the volcano analogy between zero and one. This generates a continuum of possible analogue volcanoes and gives the method considerable flexibility in scope and application. First, an automated quantitative procedure to identify sets of analogue volcanoes offers an accountable and reproducible means to use these sets to support improved hazard assessments worldwide. Second, objective provision of analogue sets can also contribute new insight into the study of fundamental magmatic or physical volcanic processes where that 
Table 1 Previous studies that used sets of analogue volcanoes for different purposes (see first column). The main criteria which served to identify these sets are indicated. The last row displays the number of studies that used each criteria, out of the total number of studies shown

\begin{tabular}{|c|c|c|c|c|c|c|c|}
\hline Use of analysis & Volcano type & $\begin{array}{l}\text { Geographic } \\
\text { area }\end{array}$ & Tectonic setting & $\begin{array}{l}\text { Magma } \\
\text { composition }\end{array}$ & $\begin{array}{l}\text { Eruption } \\
\text { size/style }\end{array}$ & $\begin{array}{l}\text { Type of } \\
\text { unrest }\end{array}$ & Reference \\
\hline Hazard assessment & & & & $\mathrm{X}$ & $\mathrm{X}$ & & Marzocchi et al. (2004) \\
\hline Volcano classification & $\mathrm{X}$ & $\mathrm{X}$ & & $\mathrm{X}$ & $\mathrm{X}$ & & Hone et al. (2007) \\
\hline Hazard assessment & & & & $\mathrm{X}$ & $\mathrm{X}$ & & Mastin et al. (2009) \\
\hline Volcano classification & $\mathrm{X}$ & & $\mathrm{X}$ & $\mathrm{X}$ & & & Sobradelo et al. (2010) \\
\hline Hazard assessment & $\mathrm{X}$ & & $\mathrm{X}$ & $\mathrm{X}$ & & & Rodado et al. (2011) \\
\hline Hazard assessment & $\mathrm{X}$ & & & & $\mathrm{X}$ & & Sandri et al. $(2012,2014)$ \\
\hline Hazard assessment & & $\mathrm{X}$ & & & $\mathrm{X}$ & & Bebbington (2014) \\
\hline Hazard assessment & $\mathrm{X}$ & & & & & & Sheldrake (2014) \\
\hline Analysis of unrest & $X$ & & & & $\mathrm{X}$ & & Acocella et al. (2015) \\
\hline Hazard assessment & $\mathrm{X}$ & & & $\mathrm{X}$ & $\mathrm{X}$ & & Ogburn et al. (2015) \\
\hline Hazard assessment & $\mathrm{X}$ & $\mathrm{X}$ & & & $\mathrm{X}$ & & Whelley et al. (2015) \\
\hline Hazard assessment & $\mathrm{X}$ & & & & $\mathrm{X}$ & & Tierz et al. (2016a) \\
\hline \multirow[t]{2}{*}{ Analysis of unrest } & $\mathrm{X}$ & & & $\mathrm{X}$ & $\mathrm{X}$ & $\mathrm{X}$ & Newhall et al. (2017) \\
\hline & $10 / 13$ & $3 / 13$ & $2 / 13$ & $7 / 13$ & $10 / 13$ & $1 / 13$ & \\
\hline
\end{tabular}

understanding is built on the observation of commonalities across individual volcanic centres. Third, data-derived analogue volcanoes can become a powerful complement to sets of analogue volcanoes obtained through expert knowledge (e.g. Marzocchi et al. 2004; Sandri et al. 2012, 2014; Newhall and Pallister 2015). Nevertheless, it is crucial to note that a careful use of those sets of automaticallyderived analogue volcanoes is necessary. The user needs to have a clear understanding of how the sets are generated and the significance and relevance of the analogue volcanoes obtained has to be assessed in the specific context of each analysis.

In the following, the source datasets and methods used to define volcano analogy are described. Then, VOLCANS is demonstrated through results for three volcanoes that (1) have characteristics that span across the different criteria (e.g. intraplate/subduction zone, basalt/andesite/dacite, shield volcano/stratovolcano); (2) have been studied to different levels of detail (i.e. some are data-rich, others are not); and (3) have recently experienced major phases of volcanic activity. The three volcanoes are as follows: Kîlauea, USA (intense phase of rifting and lava effusion from April to August 2018, approximately; Global Volcanism Program 2013, Neal et al. 2019); Fuego, Guatemala (significant explosion and devastating PDCs on 3 June 2018, Naismith et al. 2019); and Sinabung, Indonesia (long-term eruption from 2013 to 2018, and new phase starting in May 2019, with numerous PDCs and some large explosions; Global Volcanism Program 2013; Gunawan et al. 2019). Finally, the main applications and limitations of VOLCANS, including potential issues with the source datasets, are discussed.

\section{Source datasets}

The three global volcanological databases used are as follows: (1) the Holocene Global Volcanism Program database (Global Volcanism Program 2013, version 4.6.7), hereinafter GVP; (2) the volcano morphology database of Pike and Clow (1981), hereinafter Pike81; and (3) the volcano morphology database presented by Grosse et al. (2014), hereinafter Grosse14. For the Pike 81 and Grosse14 databases, only the data corresponding with volcanoes with a unique identifier matching onto the GVP database are used. Moreover, the two morphological databases are merged into a unique dataset, by assessing the correspondence and exchangeability between the variables found in each of the databases (see Online Resource 1 for more details). CSV files containing all datasets used in the analysis can be found in Online Resources 2, 3, 4 and 5.

\section{Global Volcanism Program database}

The GVP database is the global reference for the list of Holocene and Pleistocene volcanic systems in the world, but in this work, only the Holocene list is used. The GVP stores information for any volcanic system with known or suspected eruptive activity during the last $12 \mathrm{kyr}$, approximately. The data are publicly available and can be downloaded in XML format via four different searches: volcano, eruption, 
deformation and emission. Data from the volcano and eruption searches are used in this study. This includes information about volcano name, type, tectonic setting, major and minor rock types, VEI sizes of eruptions and eruptive phenomena. (see Online Resources 2, 3, 4 and 5).

\section{Pike and Clow (1981) database}

This database contains the topographic dimensions of terrestrial and some planetary volcanic systems, in particular the height, flank width, and diameter, depth and circularity of the summit depression, which sometimes corresponds to a crater and others to a caldera. The database has information for volcanoes of any type (Grosse14 does not have calderas), but the measurements were performed manually from diverse maps or aerial photographs. Therefore, if a volcano in the Pike81 database has an equivalence available in the Grosse14 database, the latter source, which is more accurate and less subjective, is used.

\section{Grosse et al. (2014) database}

The Grosse14 database contains different morphological variables relating to the edifice (height, width, average slope, etc.) and, in some cases, to the summit depression (depth, width, ellipticity, etc), derived using a common topographic source (Digital Elevation Models derived from the Shuttle Radar Topography Mission, with spatial resolution of $90 \mathrm{~m}$ ) and with developed algorithms that automatically define parameters such as the lateral extent of the volcanic edifice (Grosse et al. 2012; Euillades et al. 2013). Only positive-relief volcanoes are included in the database (predominantly shields and stratovolcanoes). Hence, caldera systems are retrieved from the Pike81 database.

\section{Methods}

The goal of VOLCANS is a quantification of single-criterion and multi-criteria analogy between volcanic systems around the world by means of five criteria, for which data for the majority of volcanoes are available in the aforementioned databases (Figs. 1 and 2): (1) tectonic setting, (2) rock geochemistry, (3) volcano morphology, (4) eruption size and (5) eruption style. Analogy is understood to be a measure of similarity and, thus, the more similar two volcanic systems, the more analogous they are. To measure this similarity, a distance metric, which ranges from zero to one, is defined for each analogy criterion (Table 2). The inverse of the distance metric represents the measure of single-criterion analogy between any two volcanoes, and it also ranges from zero to one. If the analogy is equal to zero, there is no analogy between the volcanoes. If the analogy is one, the volcanoes are interpreted to be perfect analogues, for that particular criterion. If a volcano $\mathrm{X}$ has a higher value of analogy with volcano $\mathrm{Y}$ than with volcano $\mathrm{Z}$, the interpretation is that volcano $\mathrm{Y}$ is a better analogue of volcano $\mathrm{X}$ than volcano $\mathrm{Z}$.

In order to define each distance metric, categorical variables (e.g. tectonic setting) are converted into numerical variables by applying sub-criteria which are deliberately independent of other sub-criteria and criteria. In other words, the definition of these numerical variables, and therefore the definition of analogy for each criterion, is fully independent of any other criteria (Table 2). For instance, magma geochemistry is not considered when defining the analogy in morphology (Pike 1978; Pike and Clow 1981). Only edifice dimensions are used to define such single-criterion analogy (Fig. 2). For numerical variables associated with a distribution instead of a single value (e.g. VEI class), the distance metric is the area between the empirical cumulative distribution functions (ECDFs) of any two volcanoes (Fig. 1, Table 2). Finally, for eruption style, the distance metric is calculated as the normalised sum of differences in the unit proportion of eruptions that generated diverse hazardous processes (e.g. lava flows and tephra fallout) at each volcano (Fig. 1, Table 2).

To quantify the overall analogy among any two volcanoes, $\mathrm{X}$ and $\mathrm{Y}$, single-criterion analogies are combined into a multicriteria analogy metric $\left(\mathbf{A}_{\boldsymbol{X Y}}\right)$ using the following formula:

$$
\begin{aligned}
\mathbf{A}_{X Y}= & w_{T s} \cdot A T_{s_{X Y}}+w_{G} \cdot A G_{X Y}+w_{M} \cdot A M_{X Y}+w_{S z} \\
& \cdot A S z_{X Y}+w_{S t} \cdot A S t_{X Y}
\end{aligned}
$$

where $w_{i}$ are the weights given to each single-criterion analogies (Ts: tectonic setting, G: rock geochemistry, M: volcano morphology, Sz: eruption size, St: eruption style; see Table 2). Note that some weights can be set to zero, in which case the corresponding single-criterion analogy is not considered to calculate the multi-criteria analogy. Provided that the sum of weights equals one, the multi-criteria analogy metric is a weighted average of the single-criterion analogies between volcanoes $\mathrm{X}$ and $\mathrm{Y}$. If a given volcano has no data available for a given criterion, the single-criterion analogy between this volcano and any other volcano in the database is set to zero. This is a way to avoid calculating spurious volcano analogies: even if the analogy could exist, it is not possible to corroborate this without any data available.

\section{Analogy in tectonic setting}

Given the small number of pseudo-quantitative categories used to describe tectonic setting in the GVP database, two simplified sub-criteria are used to create a variable for tectonic setting, $T_{s}$ (Fig. 1a and Table 2). These criteria are linked to (a) the primary melting mechanism of the mantle (i.e. chemically versus decompression-driven); and (b) the easiness of the path that the magma must traverse before it reaches the Earth's 
Fig. 1 Schematic showing the methodology used to define and determine quantitative metrics of single-criterion analogy for (a) tectonic setting, (b) rock geochemistry, (c) eruption size and (d) eruption style. All metrics are based on the inverse of the distance between any two volcanoes (X, Y), according to the different criteria (see Table 2 and text for more details). Abbreviations: R.: Rift; Ip.: Intraplate; S.:

Subduction; rock abbreviations as in Table 4 of Siebert et al. (2010); VEI: Volcanic Explosivity Index; Qtz: quartz; Or: orthoclase; Pl: plagioclase; Foid: feldspathoid; $h_{i}^{X}$ : frequency of eruptions of volcano $X$ for which the $i$ th hazardous process has been reported; $h_{i}^{Y}$ : frequency of eruptions of volcano $Y$ for which the $i$ th hazardous process has been reported; $\mathrm{H}$ : total number of groups of hazardous processes; WSF: water-sediment flow; PDC: pyroclastic density current
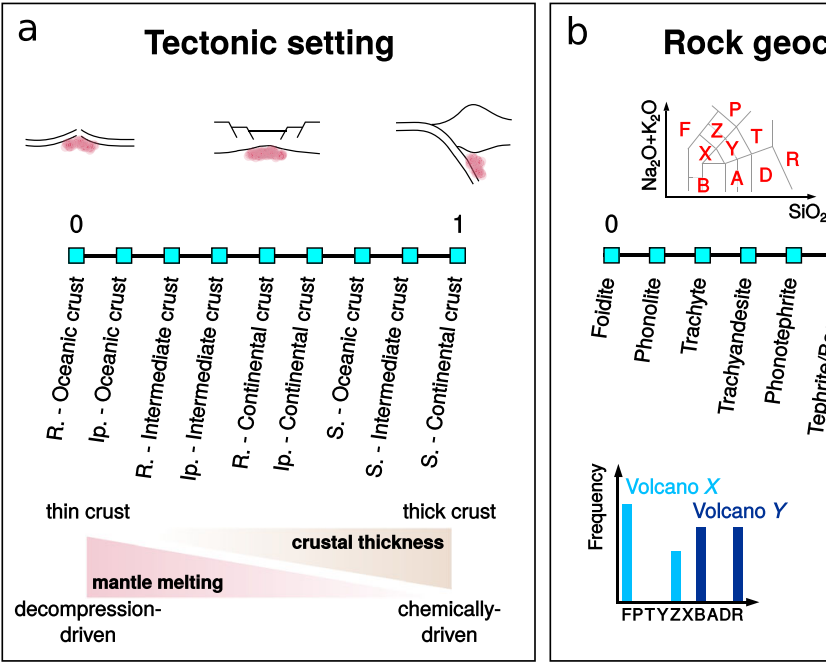

mistry
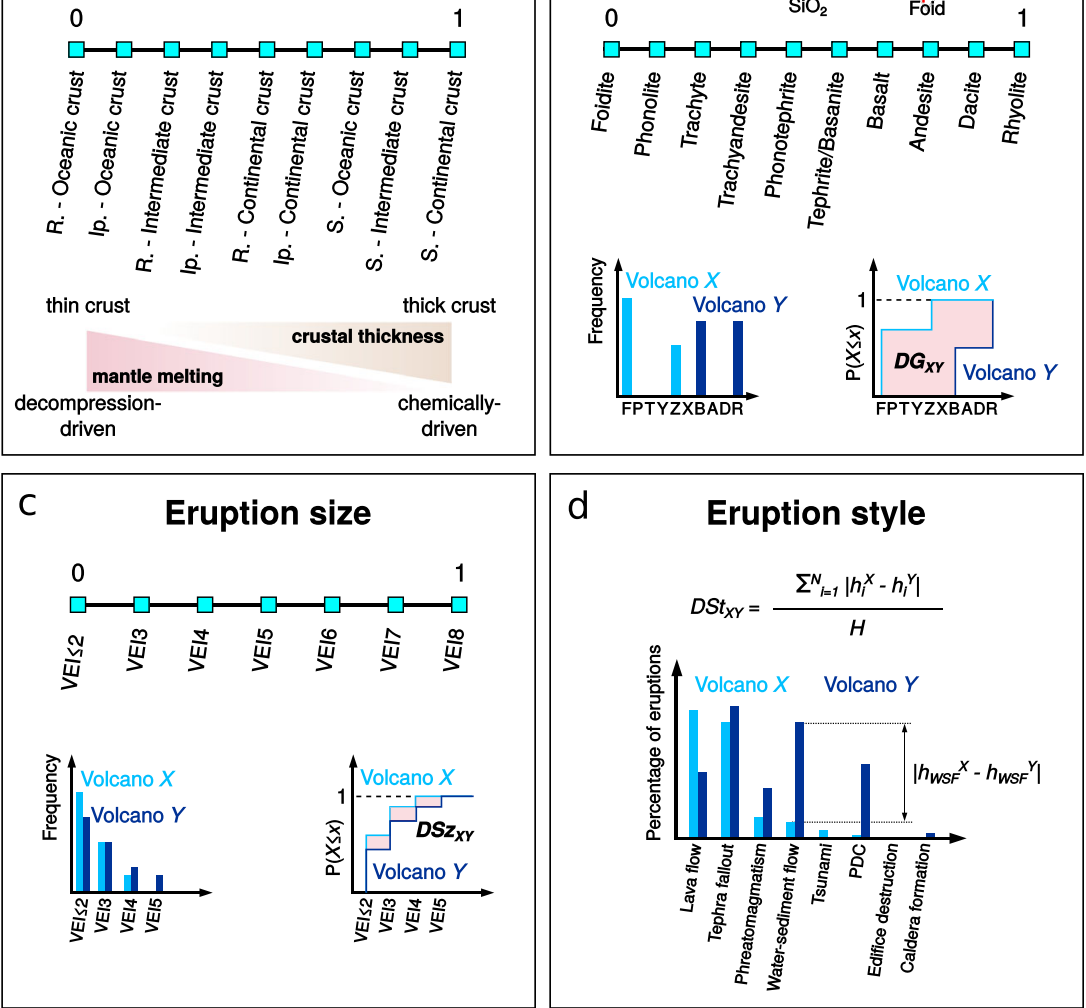

surface (Pearce 1996; Perfit and Davidson 2000). That is, it is assumed that the shallower the melting depth and the thinner the lithosphere in/above the melting zone, the easier the path towards eruption (Fig. 1a). Consequently, low values of the variable $T_{S}$ correspond with decompression-driven (rifting) magmatism over more or less thin crust while high values of the $T s$ variable correspond with subduction-zone magmatism over more or less thick crust.

\section{Analogy in rock geochemistry}

Simplified versions of the two main geochemical/ compositional diagrams to classify volcanic rocks are used to define a variable for rock geochemistry, $G$ (Total Alkali Silica, TAS, and Quartz, Alkali feldspar, Plagioclase, Feldspathoid, QAPF diagrams; Le Maitre et al. 2005; Fig. 1b). Hereinafter, the rock-type abbreviations used are the same as in the GVP database (Siebert et al. 2010; GVP 2013). According to the position in the diagrams of a given rock type compared with another rock type, a value of distance is assigned to the pair of rock types as follows: one if the rock types are adjacent; two if they are separated by one rock type, or three if they are separated by two different rock types. The sum of the values from each diagram and for each pair of rock types $i j$ is expressed as $r_{i j}$. It is a proxy for the dissimilarity between each pair of rock types: the higher the number, the more dissimilar the rocks. The numerical variable for rock geochemistry $(G)$ is defined to have as extreme points: (1) the most dissimilar rock in comparison with all the other rocks (i.e. the one with the highest sum of $r_{i j}$, over all $j$ rock types): rhyolite, R; and (2) the rock type that is the most dissimilar compared with rhyolite: i.e. foidite, F. Among the other eight rock types, the ones with the lowest value of $r_{R j}$ (dacite, D, and trachyte, $\mathrm{T}$ ) and $r_{F j}$ (tephrite/basanite/trachybasalt, $\mathrm{X}$, phonotephrite/tephri-phonolite, $\mathrm{Z}$, and phonolite, $\mathrm{P}$ ) are constrained to be the closest rock types to rhyolite and foidite, respectively. Then, all possible arrangements of rock types (around 4500 possible combinations) are explored to define the variable for rock geochemistry. The combination that minimises the total sum of $r_{i j}$ values among all the neighbouring rock types in the variable is the one selected. The ordering of the rock types is: F-P-T-Y-Z-X-B-A-D-R (Fig. 1b), which reflects differences in $\mathrm{SiO}_{2}$, total alkali $\left(\mathrm{NaO}_{2}+\mathrm{K}_{2} \mathrm{O}\right)$ and mineral contents between the rock types. Indeed, the scale divides the subalkaline/ tholeiitic (high values of the variable $G$ ) and alkaline rock series (low values of the variable $G$ ). That is, B-A-D-R are 

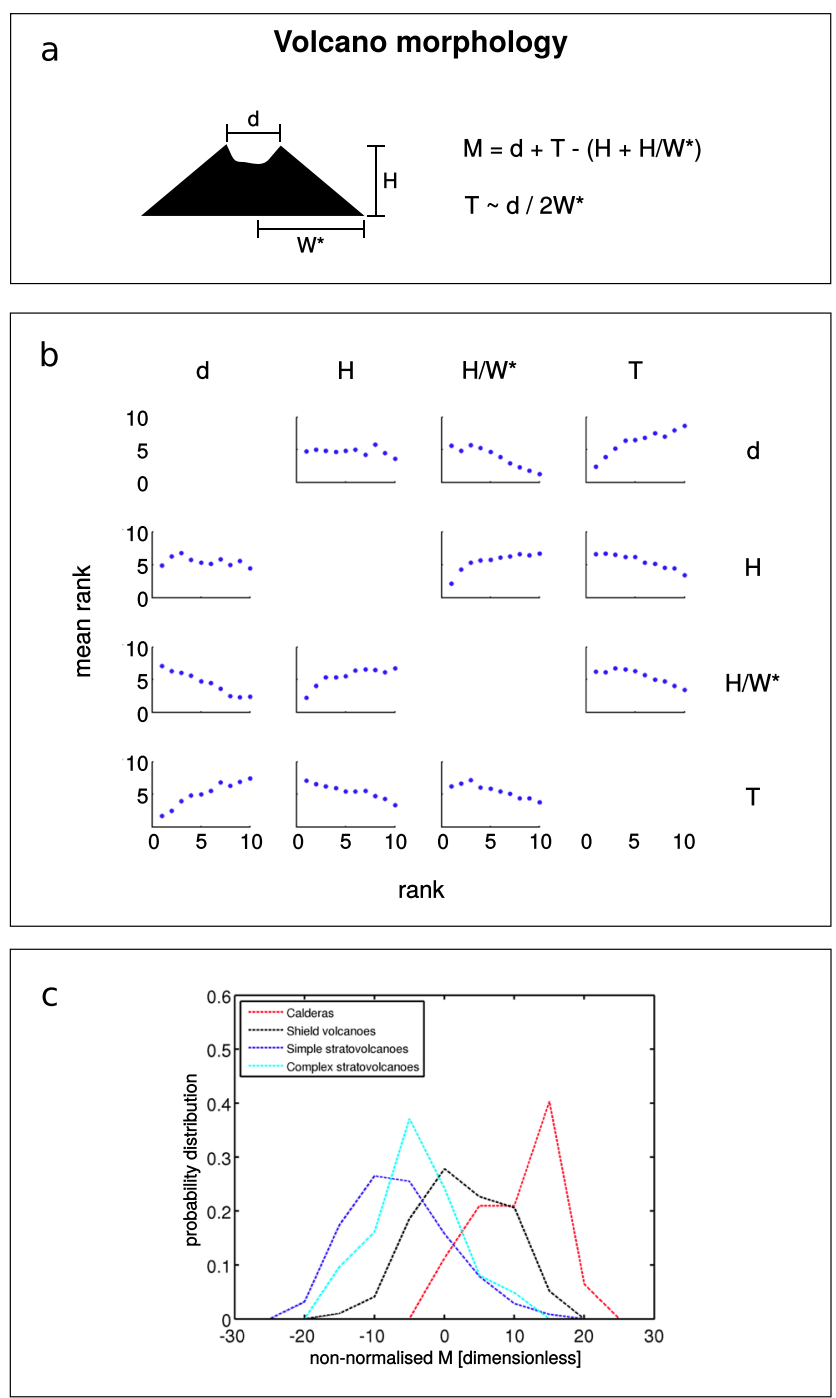

Fig. 2 Derivation of a unified variable $(M)$ to measure volcano morphology: (a) schematic showing the dimensions of the volcanic edifice and the formula used to calculate $M$; (b) trends in the dimensions of volcanic edifices according to the morphological databases of Pike and Clow (1981) and Grosse et al. (2014); the graphs on the columns show the rank value ( $x$-axis) for the variable indicated on each column against the mean rank value (y-axis) for the variable indicated on each row. $d$ : crater diameter; $H$ : height of rim crest above prevolcano topography; $W^{*}$ : half width of the volcano; T: truncation of the edifice; (c) probability distributions of $M$ (non-normalised) for four classes of Primary Volcano Types (a variable in the GVP database)

closer to each other in comparison to the other, more alkalirich rock types, as reported by Le Bas et al. (1986). However, it must be noted that the geochemical data for many volcanoes in the GVP database may come from general rock definitions (e.g. basalt or andesite) that do not differentiate between subalkaline and alkaline rock suites (Siebert et al. 2010).

In order to account for intra-volcano geochemical variability, all major and minor rock types in the GVP database are considered, for any given volcano. Each major rock type is counted as two data points and each minor rock type as one data point to create normalised histograms and ECDFs of rock types, one for each volcano. The measure of single-criterion analogy for rock geochemistry between volcanoes $\mathrm{X}, \mathrm{Y}$, is the inverse of the area between their ECDFs (Fig. 1b). In other words, it is a measure of the overlap between the histograms of rock types for volcanoes X, Y (Fig. 1b, Table 2).

\section{Analogy in volcano morphology}

Volcano morphology is derived based on (Fig. 2) crater/ caldera diameter $(d)$, height of rim crest above pre-volcano topography $(H)$, ratio between the height and half-width of the volcanic edifice $\left(H / W^{*}\right)$ and truncation parameter of the volcanic edifice $\left(T \sim d / 2 W^{*}\right)$. The values of all of these variables have been checked to be consistent and compatible across the two volcano morphology databases (see Online Resource 1).

Based on its ECDF, each variable is divided into 10percentiles-wide classes or ranks. Each rank is assigned a value from 1 (i.e. $0-10$ th percentiles) to 10 (i.e. $90-100$ th percentiles). In Fig. 2b, the values of each rank for a given variable are plotted against the mean value of the rank for another variable. This shows the general underlying trends between the different variables, without these trends being obscured by the dense continuum of morphologies that exist in the world's volcanoes (Grosse et al. 2014). Small values of $d$ and $T$ tend to occur together with high values of $H$ and $H / W^{*}$ (Fig. 2b). This corresponds well with the view of high volcanic edifices (e.g. stratovolcanoes) having high height-to-width ratios, small craters and relatively low truncation values (Grosse et al. 2009, 2014). On the contrary, low-altitude edifices (e.g. shields and calderas) are commonly conceived to have low height-towidth ratios, large craters/calderas and sometimes high truncation (Pike 1978; Pike and Clow 1981). The merged dataset used here confirms these trends. Therefore, the morphology of a volcano is described by variable $M$ :

$M=d+T-\left(H+H / W^{*}\right)$

where $d, T, H, H / W^{*}$ correspond to the aforementioned rank values (from 1 to 10), for any given volcano. The $M$ variable separates volcanoes that have low-height, gentle-slope, highly-truncated edifices with large craters (high values of $M$ ) from volcanoes that have high, steep-slope, lowtruncation edifices with small craters (low values of $M$ ). All entries in the merged morphology database have an entry for the variables $T, H$ and $H / W^{*}$. However, some of the stratovolcanoes taken from the Grosse14 database lack a measure of the variable $d$, most commonly linked with very small craters (Grosse et al. 2014). In such cases, a rank value of zero is used.

Figure 2c shows the distributions of $M$ values obtained when grouping volcanic systems according to their Primary 
Table 2 Framework to define and determine single-criterion analogy metrics for five different volcanological criteria. "D" stands for the absolute distance between any two volcanoes $(\mathrm{X}, \mathrm{Y})$ within a given criterion and it is measured in slightly different ways for the different criteria (see also Figs. 1 and 2). "A" stands for single-criterion analogy and it is the inverse of the distance " $\mathrm{D}$ ". Multi-criteria volcano analogy is defined as a weighted sum of single-criterion analogies (see Eq. (1) and text for more details). TAS, total alkali silica; $Q A P F$, Quartz-Alkali feldsparPlagioclase-Feldspathoid; VEI, Volcano Explosivity Index; $E C D F$, empirical cumulative distribution function (letter " $F$ " in the distance-metric column is equivalent to ECDF); $T s$, tectonic setting; $G$, rock geochemistry; $M$, volcano morphology; $S z$, eruption size; $S t$, eruption style; $h_{i}$, frequency of eruptions with a given hazardous phenomena $i ; H$, total number of groups of hazardous phenomena (see Table 4)

\begin{tabular}{|c|c|c|c|c|}
\hline Criterion & Sub-criteria & Type of distance metric & Distance metric & Analogy metric \\
\hline Tectonic setting & $\begin{array}{l}\text { Crustal thickness } \\
\text { Mantle-melting mechanism }\end{array}$ & Linear & $\mathrm{DTs}_{\mathrm{XY}}=\left|\mathrm{Ts}_{\mathrm{X}}-\mathrm{T} \mathrm{s}_{\mathrm{Y}}\right|$ & $\mathrm{ATs}_{\mathrm{XY}}=1-\mathrm{DTs}_{\mathrm{XY}}$ \\
\hline Rock geochemistry & $\begin{array}{l}\text { TAS diagram } \\
\text { QAPF diagram }\end{array}$ & Area between ECDFs & $\mathrm{DG}_{\mathrm{XY}}=\left|\mathrm{F}_{\mathrm{GX}}-\mathrm{F}_{\mathrm{GY}}\right|$ & $\mathrm{AG}_{\mathrm{XY}}=1-\mathrm{DG}_{\mathrm{XY}}$ \\
\hline Volcano morphology & $\begin{array}{l}\text { Edifice height } \\
\text { Edifice height/half-width ratio } \\
\text { 'Crater' diameter } \\
\text { Summit width/edifice width ratio }\end{array}$ & Linear & $\mathrm{DM}_{\mathrm{XY}}=\left|\mathrm{M}_{\mathrm{X}}-\mathrm{M}_{\mathrm{Y}}\right|$ & $\mathrm{AM}_{\mathrm{XY}}=1-\mathrm{DM}_{\mathrm{XY}}$ \\
\hline Eruption size & Distribution of VEI sizes & Area between ECDFs & $\mathrm{DSZ}_{\mathrm{XY}}=\left|\mathrm{F}_{\mathrm{SzX}}-\mathrm{F}_{\mathrm{SZY}}\right|$ & $\mathrm{ASZ}_{\mathrm{XY}}=1-\mathrm{DSZ}_{\mathrm{XY}}$ \\
\hline Eruption style & Grouping of hazardous phenomena & Sum of frequency differences & $\mathrm{DSt}_{\mathrm{XY}}=\left(\Sigma_{\mathrm{i}}^{\mathrm{N}}\left|\mathrm{h}_{\mathrm{Xi}}-\mathrm{h}_{\mathrm{Yi}}\right|\right) / \mathrm{H}$ & $\mathrm{ASt}_{\mathrm{XY}}=1-\mathrm{DSt}_{\mathrm{XY}}$ \\
\hline
\end{tabular}

Volcano Type defined in the GVP database. The distributions of $M$ for simple and complex/compound stratovolcanoes, shield volcanoes and caldera systems are significantly different (Fig. 2c). Table 3 reports the mean values of $M$ for all these main groups. Given the consistent separation of volcano types in different populations of the $M$ variable (Fig. 2c), mean values of $M$ are assigned to all the GVP entries that are not described in the merged morphological database but that are classified as stratovolcanoes, shields or calderas by the GVP database according to their Primary Volcano Type. In the case of volcanic fields, a (normalised) value of $M=1$ is assigned, this being purely based on their general morphology, which features large lateral extension and very limited vertical extent.

\section{Analogy in eruption size}

For volcanoes with an eruption record in the GVP database, the volcano analogy in terms of eruption size and eruption style is assessed. The approach of merging the whole recorded dataset of eruption sizes and hazardous phenomena for any given volcano assumes stationarity in activity, at least when averaged over the Holocene. Nonetheless, it is acknowledged that analyses of the eruptive histories at individual volcanoes over shorter periods of time commonly evidence nonstationary behaviours (e.g. Bebbington 2008; Marzocchi and Bebbington 2012; Connor et al. 2015).

Given that VEI 2 is the default assignment in the GVP database and the fact that effusive (VEI 0) and very small explosive eruptions (VEI 1-2) are particularly underreported (De la Cruz-Reyna 1991; Mead and Magill 2014), all eruptions with VEI $\leq 2$ are grouped together (Mead and Magill 2014). Under-recording issues are expected to affect any analysis of frequency-size of eruptions, independently of whether VEI or eruption magnitude data are used (Rougier et al. 2016). A simplified approach to compensate for underrecording is implemented: (1) a suitable function to model the probability of recording an eruption of a given VEI $x$, at time $t$, is identified; and (2) this probability is used to extrapolate the number of eruptions of that VEI that might have been missed at the specific volcano. Thus, the total number of eruptions of a given VEI $(x)$ that have occurred at a given volcanic system is estimated as:

$E_{R}(x)=E_{R 1}(x)+E_{R 2}(x)$

where $E_{R 1}(x)$ denotes the total number of eruptions of VEI $x$ that occurred before the date of completeness $(k$, considered as the date after which the recording probability is one; Mead and Magill 2014) and $E_{R 2}(x)$ denotes the total number of eruptions of VEI $x$ that occurred after the date of completeness $k$. For each volcano and eruption size, if $E_{R}(x)$ is not an integer, its value is rounded to the closest integer. $E_{R 2}(x)$ is calculated directly from summing up the number of recorded eruptions in the GVP database, for a given volcano after time $k$, given that the recording probability is assumed to be one. $E_{R 1}(x)$ is calculated as follows:

$E_{R 1}(x)=\frac{\sum_{t=t_{1}}^{k} E_{r 1}(t, x)}{p(t, x)}$

where $p(t, x)$ is the recording probability of an eruption of VEI $x$ that occurs at time $t \leq k$ and $E_{r 1}(t, x)$ denotes the indicator function for any eruption of VEI $x$ that occurred at time $t \leq k$. 
Table 3 Summary of the minimum, maximum and mean values of the morphology variable $(M)$ for simple, complex and all stratovolcanoes, shield volcanoes and caldera systems, all according to the assigment of "Primary Volcano Type" stored in the GVP database

\begin{tabular}{|c|c|c|c|c|c|}
\hline & Simple stratovolcanoes & Complex stratovolcanoes & All stratovolcanoes & Shield volcanoes & Calderas \\
\hline Minimum M & 0.000 & 0.105 & 0.000 & 0.158 & 0.447 \\
\hline Mean M & 0.333 & 0.390 & 0.338 & 0.567 & 0.782 \\
\hline Maximum M & 0.947 & 0.816 & 0.947 & 0.921 & 0.974 \\
\hline
\end{tabular}

The sum of $E_{r 1}(t, x)$ is the total number of eruptions of size $x$ recorded before time $k$.

A single-change-point presence function is used to model the recording probability (Furlan 2010; Mead and Magill 2014):

$p(t, x)=\left\{\begin{array}{cc}\frac{1}{1+e^{-a-\beta x}} & t \leq k \\ 1 & t>k\end{array}\right\}$

where $\alpha, \beta$ are the parameters controlling the scale and shape of the function. The date of completeness $k$ is taken from Table 1 in Mead and Magill (2014), in particular the median value of the change point posterior distribution in their model, for any volcano in a given country. In the absence of data at the country scale, the $k$ value available for the corresponding region is used.

The $\alpha$ and $\beta$ parameters are selected following two naive assumptions. Before the date of completeness: (a) VEI $=0$ eruptions are "exceptionally unlikely" (Mastrandrea et al. 2010 ) to be recorded, i.e. $p(t, 0)=0.01$; and (b) VEI $=8$ eruptions are "virtually certain" (Mastrandrea et al. 2010) to be recorded, i.e. $p(t, 8)=0.99$. It is noted that the latter may actually be an overestimation given that around $70 \%$ of the world's Holocene volcanoes are very poorly studied (Loughlin et al. 2015). These two assumptions provide a parameterisation for the presence function in Eq. (5): $\alpha=-$ 4.595, $\beta=1.150$. Using this parameterisation, a VEI 4 eruption, for instance, has a $50 \%$ probability of being recorded, before the date of completeness $k$.

The choice of a single-change-point function can be questionable at global scales (Deligne et al. 2010; Rougier et al. 2016) but may be adequate for many countries and regions, especially for small-size eruptions (Jenkins et al. 2012) and/or for those areas where geological data are scarce compared to historical data (Mead and Magill 2014). In our study, this choice is a convenient one, given that all the eruptions that occurred at time $t \leq k$ can then be cumulated to estimate the total number of eruptions that might have happened over that time span. This partially relaxes the issues of under-recording in the GVP database.

Normalised VEI sizes are used as the variable for eruption size and the value of $E_{R}(x)$ at each volcano is used to build a histogram, and an ECDF, which estimates the frequency- magnitude distribution at each specific volcano (given eruption). The area between the ECDFs of any two volcanoes, $\mathrm{X}$ and $\mathrm{Y}$, is used as the distance metric for the eruption-size criterion. The associated single-criterion analogy is the inverse of this distance metric (Fig. 1c and Table 2).

\section{Analogy in eruption style}

In order to estimate single-criterion analogy in eruption style, data on hazardous phenomena are used. A total number of 22 Event types from the GVP database are grouped into eight groups of hazardous processes (Fig. 1d, Table 4, Online Resource 1). At each particular volcano, the total number of occurrences of each group is divided by the total number of eruptions with eruption-style data, to calculate the proportion of eruptions that generated each group of hazardous phenomena. To avoid duplications, two or more events of the same group occurring during the same eruption are counted as only one occurrence of the group. The normalised sum of differences between the proportions of the different hazardous processes is used as the distance metric for the eruption-style analogy between volcanoes X, Y (DSt $t_{X}$, Fig. $1 \mathrm{~b}$ and Table 2):

$D S t_{X Y}=\frac{\sum_{i=1}^{N}\left|h_{i}^{X}-h_{i}^{Y}\right|}{H}$

where $H$ is the total number of groups of hazardous phenomena, and $h_{i}^{X}$ and $h_{i}^{Y}$ are the frequencies of occurrence (or proportions) for the $i$ th group and volcanoes $X$ and $Y$, respectively. Thus, the analogy in eruption style can be interpreted as an average difference between the proportions of the different hazardous phenomena. It is also noted that Eq. (6) penalises both differences in the frequency of occurrence and data scarcity in the groups of hazardous phenomena, for if there is no data for a given group, $h_{i}$ will be equal to zero.

\section{Results}

The content and functionality of VOLCANS is illustrated by analysing different sets of analogues for Kîlauea (USA), 
Table 4 List of the event types used from the GVP database and their assigned correspondence in terms of 8 groups of physical hazardous processes

\begin{tabular}{ll}
\hline Event type (as in GVP) & Group of physical processes \\
\hline Lava flow(s) & Lava flow and/or fountaining \\
Lava fountains & Lava flow and/or fountaining \\
Fissure formation & Lava flow and/or fountaining \\
Cinder cone formation & Lava flow and/or fountaining \\
Scoria & Lava flow and/or fountaining \\
Blocks & Ballistics and tephra \\
Bombs & Ballistics and tephra \\
Tephra & Ballistics and tephra \\
Pumice & Ballistics and tephra \\
Ash & Ballistics and tephra \\
Lapilli & Ballistics and tephra \\
Explosion & Ballistics and tephra \\
Eruption cloud & Ballistics and tephra \\
Phreatic activity & Phreatic and phreatomagmatic activity \\
Phreatomagmatic eruption & Phreatic and phreatomagmatic activity \\
Lahar or mudflow & Water-sediment flows \\
Jokulhaup & Water-sediment flows \\
Tsunami & Tsunamis \\
Pyroclastic flow & Pyroclastic density currents \\
Directed explosion & Pyroclastic density currents \\
Edifice destroyed & Edifice collapse/destruction \\
Caldera formation & Caldera formation \\
\hline & \\
\hline
\end{tabular}

Fuego (Guatemala) and Sinabung (Indonesia). Figure 3 contains a summary of the ID profile of each volcano, that is, the data available for each analogy criterion. Single-criterion and multi-criteria analogies are described and top analogue volcanoes (e.g. top 10 or top 20) are identified. In the case of multi-criteria searches, three different weighting schemes are explored: (A) equal weighting, i.e. all criteria count the same to calculate the volcano analogy, (B) eruption size and style are the only criteria used (equal weight between them) and $(\mathrm{C})$ rock geochemistry and volcano morphology are the only criteria used (equal weight between them). These weighting schemes, which explore the most-used criteria to search for analogue volcanoes (Table 1), are purely illustrative. The particular choice of weighting scheme, which obviously alters the set of analogue volcanoes obtained, will depend on the specific goals and needs of each user. The significant advantage of VOLCANS is that it provides the user with full flexibility about this choice. Results revealed that some criteria were non-differentiating while others were differentiating. Non-differentiating criteria are defined as those that, for a specific volcano, result in tens or hundreds of analogue volcanoes with the same value of analogy (including one). Such criteria cannot be used to identify reduced sets of analogue volcanoes. Differentiating criteria, on the other hand, result in much fewer analogue volcanoes with the same value of analogy.

\section{Kilauea, USA}

Kîlauea is a basaltic shield volcano located on an oceanic intraplate tectonic setting in relation to the presence of the Hawaiian hot spot (Decker et al. 1987; Carey et al. 2015). It formed on the eastern flank of the large Mauna Loa shield volcano at least $350 \mathrm{ka}$ (Quane et al. 2000). Over the past $200 \mathrm{yr}$, its eruptive products have mainly consisted of lava flows but tephra layers have been also identified in the Pleistocene and Holocene (Easton 1987; Fiske et al. 2009). In historical times, phreatomagmatic and phreatic explosive eruptions have occurred (McPhie et al. 1990; Dvorak 1992; Mastin et al. 2004). Over a longer timescale of the past 2500 yr, Swanson et al. (2014) identified several shifts between periods dominated by either effusive or explosive volcanic activity, each of those periods lasting for several centuries. Although erupted magma volumes were significantly higher during effusive periods, the total duration of explosive periods was calculated as about $500 \mathrm{yr}$ longer (Swanson et al. 2014).

Single-criterion analogies for tectonic setting, rock geochemistry and volcano morphology give rise to many perfect analogues to Kîlauea (i.e. analogy equal to one), given its relatively simple ID profile for those criteria (Fig. 3). In terms of eruption size, a large number of volcanoes share a high value of single-criterion analogy with Kîlauea $(\mathrm{ASz}=$ 0.9989). Only one volcano (Piton de la Fournaise) has a slightly higher value of eruption-size analogy $(\mathrm{ASz}=0.9992)$. This is related to the fact that, similarly to Kilauea, over $99 \%$ of the eruptions at Piton de la Fournaise have been $\mathrm{VEI} \leq 2$, but there is also one large explosive event, a VEI 5 eruption (the Bellecombe Ash Member eruption, Global Volcanism Program 2013; although the eruption is contested by Ort et al. 2016, to have been actually three eruptions, adding up to volumes of around $0.3 \mathrm{~km}^{3}$ - VEI 4-and column heights of $8 \mathrm{~km}$, at maximum). At Kîlauea, the largest explosive eruption in its eruptive record is a VEI 4 eruption (Keanakāko' $i$ ash, $1790 \mathrm{AD}$; which is interpreted to have been a long-lasting series of events instead of a single eruption, McPhie et al. 1990; Mastin et al. 2004; Swanson et al. 2014; Swanson and Houghton 2018). In terms of eruption style, it is possible to identify the top 10 analogue volcanoes to Kîlauea (Table 5). These are predominantly basaltic to dacitic volcanoes that, on average, are characterised by producing lava flows and/or fountaining in almost every eruption (>92\% of them), ballistics and tephra in 1 out of 3 eruptions, and phreatic/ phreatomagmatic activity only occasionally (about $2 \%$ of the eruptions).

Multi-criteria searches of analogue volcanoes to Kïlauea with scheme A (equal weight) bring a mixture of analogue 

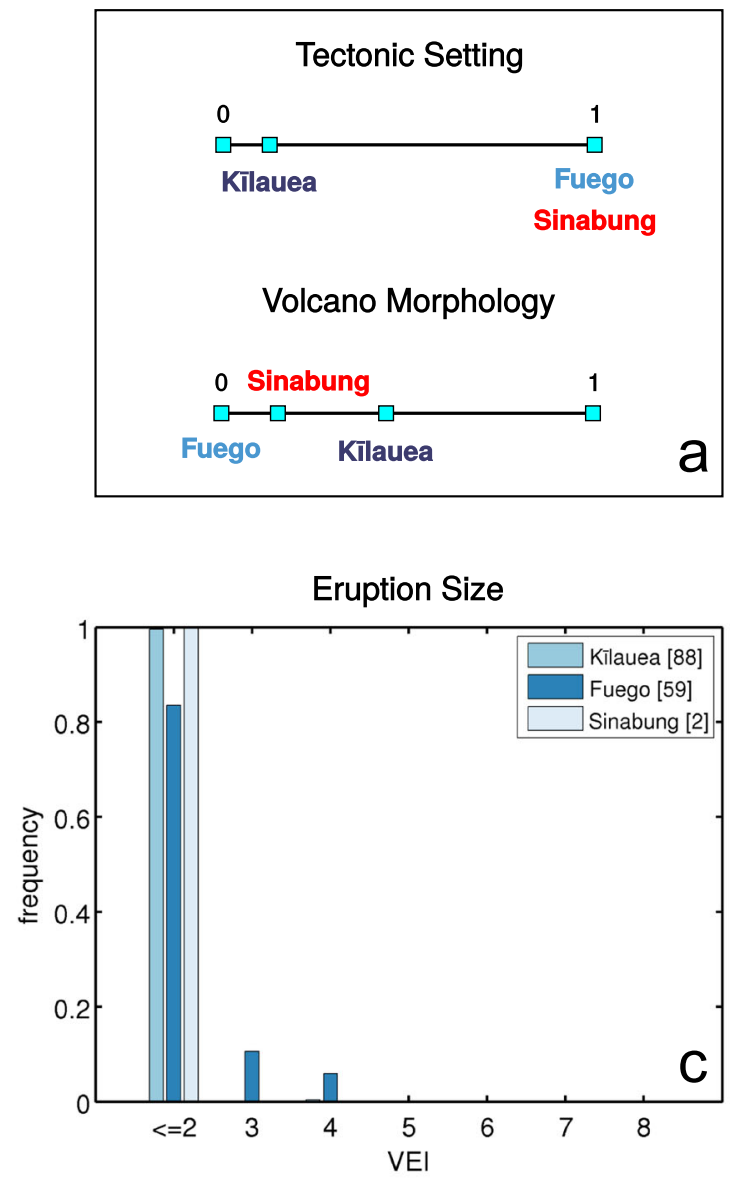

Fig. 3 ID profiles for the three example volcanoes in the study, Kîlauea (USA), Fuego (Guatemala) and Sinabung (Indonesia), for (a) tectonic setting and volcano morphology; (b) rock geochemistry (rock-type abbreviations as in Fig. 1); (c) eruption size (VEI: Volcanic Explosivity

volcanoes (Table 5): some of them can be linked to top 10 analogues in eruption size and style but others, like the top 1 and 3 analogue volcanoes (Mauna Loa and Karthala, respectively), are not identified when using single-criterion searches. The top 10 list for scheme B (eruption size and style only) is dominated by the top 10 eruption-style analogues (Table 5), but the use of both eruption size and style provides new candidates that do not arise in the single-criterion search: e.g. Mauna Loa and Hualālai. Finally, the top 10 list of analogue volcanoes for scheme $\mathrm{C}$ (rock geochemistry and volcano morphology only) has a few examples from lists A and B but, generally, contains volcanoes that are not listed in the other searches (Table 5). This suggests that these predominantly basaltic volcanoes, with morphologies similar to Kîlauea, may not necessarily show eruption sizes and styles closely matching those of Kîlauea volcano.

The ratios between different single-criterion analogies for the top 20 analogue volcanoes identified from different weighting schemes are shown in Fig. 4. It is noted that the fact that a weighting scheme uses two analogy criteria only
Rock Geochemistry

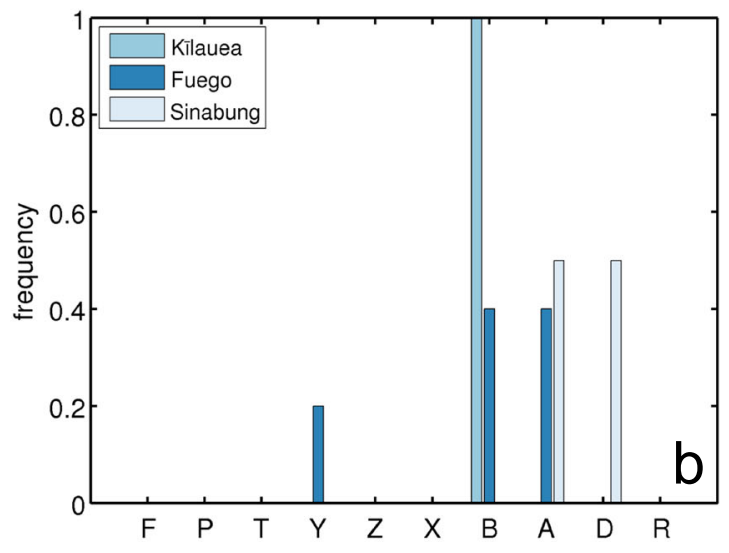

Eruption Style

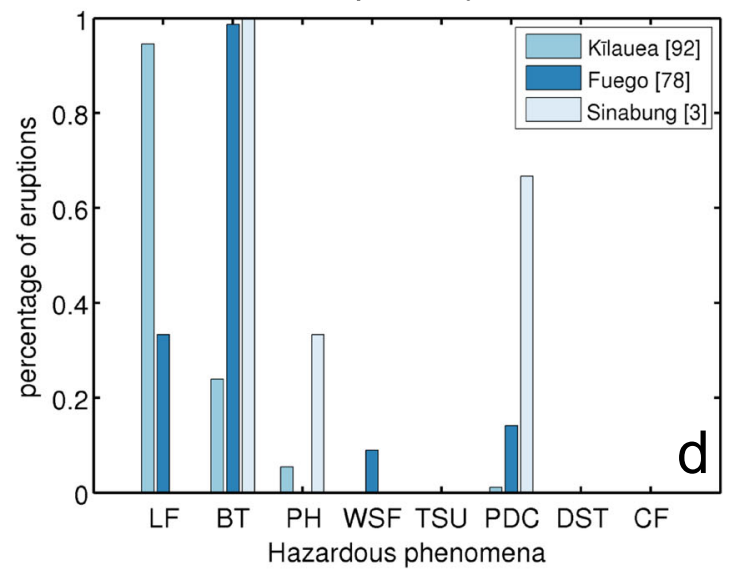

Index); (d) eruption style (LF: lava flows and/or fountaining; BT: ballistics and tephra; PH: phreatic and phreatomagmatic activity; WSF: watersediment flows; TSU: tsunamis; PDC: pyroclastic density currents; DST: edifice collapse/destruction; CF: caldera formation)

(e.g. eruption size and style for scheme B) does not imply that the identified top 20 analogues do not have data for the other analogy criteria (e.g. rock geochemistry or volcano morphology). Analogy in morphology and geochemistry are systematically higher than analogy in either eruption size or style, for the analogue volcanoes obtained with scheme C. Likewise, the analogue volcanoes derived from scheme B have systematically higher values of analogy in eruption size and style compared with analogy in morphology and geochemistry (Fig. 4b, c). In other words, analogy in eruption size and style and analogy in geochemistry and morphology for Kīlauea volcano are decoupled: volcanoes with rock geochemistries and/or morphologies the most similar to Kîlauea (top 20, scheme C) do not necessarily show the same highest degree of similarity in terms of eruption size and/or style (top 20 , scheme B). Otherwise, the values of the ratios between analogy criteria would be very similar. Therefore, the degree of decoupling between different single criteria for each volcano can be assessed as the dispersion or distance between data points for different weighting schemes. 
Table 5 Top 10 analogue volcanoes to Kīlauea, Fuego and Sinabung volcanoes, according to different single-criterion analogy metrics and three different weighting schemes to assess multi-criteria analogy. ISO Alpha-2 country codes for each volcano are indicated between round brackets. Number of eruptions with VEI assigned that are available in the GVP database are reported between square brackets for each analogue volcano in scheme B

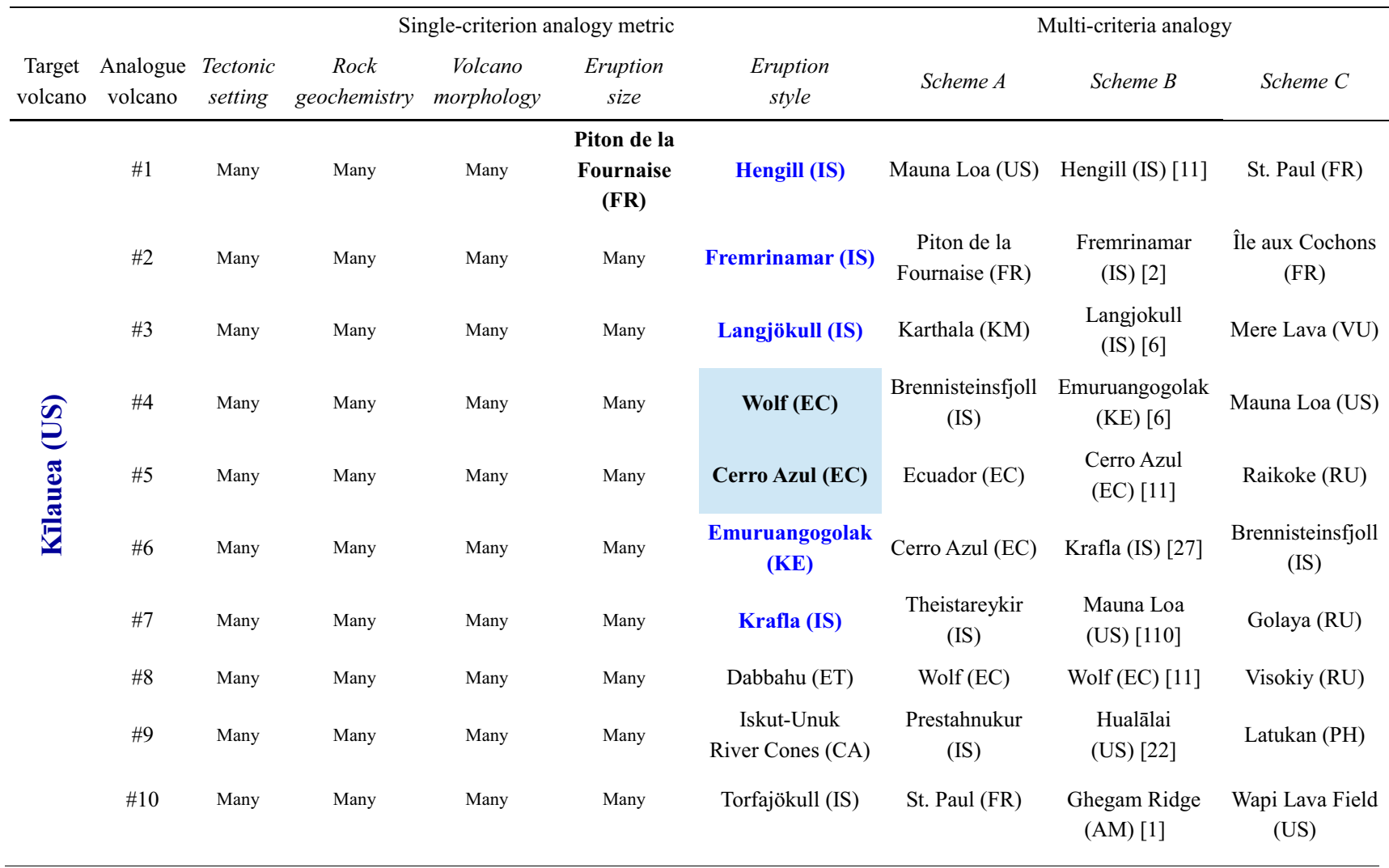

\begin{tabular}{|c|c|c|c|c|c|c|c|c|c|}
\hline $\begin{array}{l}\text { Target } \\
\text { volcano }\end{array}$ & $\begin{array}{l}\text { Analogue } \\
\text { volcano }\end{array}$ & $\begin{array}{c}\text { Tectonic } \\
\text { setting }\end{array}$ & $\begin{array}{c}\text { Rock } \\
\text { geochemistry }\end{array}$ & $\begin{array}{c}\text { Volcano } \\
\text { morphology }\end{array}$ & $\begin{array}{l}\text { Eruption } \\
\text { size }\end{array}$ & $\begin{array}{l}\text { Eruption } \\
\text { style }\end{array}$ & Scheme A & Scheme B & Scheme C \\
\hline \multirow{10}{*}{ 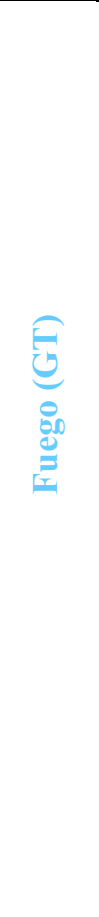 } & $\# 1$ & Many & $\begin{array}{l}\text { Great Sitkin } \\
\text { (US) }\end{array}$ & $\begin{array}{c}\text { Koryasky } \\
\text { (RU) }\end{array}$ & $\begin{array}{c}\text { Tenerife } \\
\text { (ES) }\end{array}$ & $\begin{array}{l}\text { Chikurachki } \\
\text { (RU) }\end{array}$ & $\begin{array}{l}\text { Klyuchevskoy } \\
\text { (RU) }\end{array}$ & $\begin{array}{l}\text { Momotombo } \\
\text { (NI) [16] }\end{array}$ & Tacaná (MX-GT) \\
\hline & \#2 & Many & $\begin{array}{c}\text { São Jorge } \\
\text { (PT) }\end{array}$ & $\begin{array}{c}\text { Kronotsky } \\
\text { (RU) }\end{array}$ & $\begin{array}{c}\text { Pagan } \\
\text { (US) }\end{array}$ & $\begin{array}{l}\text { Pavlof } \\
\text { (US) }\end{array}$ & Semeru (ID) & Pagan (US) [17] & Koryaksky (RU) \\
\hline & \#3 & Many & $\begin{array}{c}\text { Garibaldi } \\
\text { Lake (CA) }\end{array}$ & $\begin{array}{c}\text { Baker } \\
\text { (US) }\end{array}$ & $\begin{array}{l}\text { Llaima } \\
\text { (CL) }\end{array}$ & Momotombo (NI) & Osorno (CL) & Pavlof (US) [42] & Kronotsky (RU) \\
\hline & \#4 & Many & $\begin{array}{c}\text { Michoacán- } \\
\text { Guanajuato } \\
\text { (MX) }\end{array}$ & $\begin{array}{c}\text { Tacaná } \\
\text { (MX-GT) }\end{array}$ & $\begin{array}{l}\text { Rincón de la } \\
\text { Vieja (CR) }\end{array}$ & $\begin{array}{l}\text { Pacaya } \\
\text { (GT) }\end{array}$ & Merbabu (ID) & $\begin{array}{l}\text { Klyuchevskoy } \\
\text { (RU) [101] }\end{array}$ & Kamen (RU) \\
\hline & $\# 5$ & Many & $\begin{array}{c}\text { Mount St } \\
\text { Helens (US) }\end{array}$ & $\begin{array}{l}\text { Tajumulco } \\
\text { (GT) }\end{array}$ & $\begin{array}{c}\text { Asamayama } \\
\text { (JP) }\end{array}$ & $\begin{array}{l}\text { Villarrica } \\
\text { (CL) }\end{array}$ & Tacaná (MX-GT) & $\begin{array}{l}\text { Karangetang } \\
\text { (ID) [53] }\end{array}$ & $\begin{array}{l}\text { Klyuchevskoy } \\
\text { (RU) }\end{array}$ \\
\hline & $\# 6$ & Many & $\begin{array}{l}\text { Lamongan } \\
\text { (ID) }\end{array}$ & $\begin{array}{l}\text { Santa Maria } \\
\text { (GT) }\end{array}$ & $\begin{array}{l}\text { Manam } \\
(\mathrm{PG})\end{array}$ & $\begin{array}{l}\text { Semeru } \\
\text { (ID) }\end{array}$ & $\begin{array}{l}\text { Chikurachki } \\
\text { (RU) }\end{array}$ & $\begin{array}{l}\text { Villarrica } \\
\text { (CL) [123] }\end{array}$ & Merbabu (ID) \\
\hline & \#7 & Many & $\begin{array}{c}\text { Kasuga } 2 \\
\text { (US) }\end{array}$ & $\begin{array}{l}\text { Acatenango } \\
\text { (GT) }\end{array}$ & $\begin{array}{c}\text { Momotombo } \\
\text { (NI) }\end{array}$ & Karymsky (RU) & Pavlof (US) & $\begin{array}{l}\text { Semeru } \\
\text { (ID) [58] }\end{array}$ & Semeru (ID) \\
\hline & $\# 8$ & Many & $\begin{array}{l}\text { La Gloria } \\
\text { (MX) }\end{array}$ & $\begin{array}{l}\text { Sangay } \\
\text { (EC) }\end{array}$ & $\begin{array}{l}\text { Fujisan } \\
\text { (JP) }\end{array}$ & Karangetang (ID) & Baker (US) & $\begin{array}{l}\text { Lewotobi } \\
\text { (ID) [23] }\end{array}$ & Mayon (PH) \\
\hline & $\# 9$ & Many & $\begin{array}{c}\text { Chichinautzin } \\
\text { (MX) }\end{array}$ & $\begin{array}{l}\text { Lanín } \\
\text { (CL-AR) }\end{array}$ & $\begin{array}{c}\text { Reykjanes } \\
\text { (IS) }\end{array}$ & $\begin{array}{c}\text { Klyuchevskoy } \\
\text { (RU) }\end{array}$ & Acatenango (GT) & $\begin{array}{l}\text { Karymsky } \\
\text { (RU) [40] }\end{array}$ & Vilyuchik (RU) \\
\hline & $\# 10$ & Many & Many & $\begin{array}{l}\text { Arenales } \\
\text { (CL) }\end{array}$ & Many & Towada (JP) & Shishaldin (US) & $\begin{array}{l}\text { Ambrym } \\
\text { (VU) [49] }\end{array}$ & Sangay (EC) \\
\hline
\end{tabular}


Table 5 (continued)

\begin{tabular}{|c|c|c|c|c|c|c|c|c|c|}
\hline $\begin{array}{c}\text { Target } \\
\text { volcano }\end{array}$ & $\begin{array}{l}\text { Analogue } \\
\text { volcano }\end{array}$ & $\begin{array}{l}\text { Tectonic } \\
\text { setting }\end{array}$ & $\begin{array}{c}\text { Rock } \\
\text { geochemistry }\end{array}$ & $\begin{array}{l}\text { Volcano } \\
\text { morphology }\end{array}$ & $\begin{array}{l}\text { Eruption } \\
\text { size }\end{array}$ & $\begin{array}{l}\text { Eruption } \\
\text { style }\end{array}$ & Scheme A & Scheme B & Scheme C \\
\hline \multirow{10}{*}{ 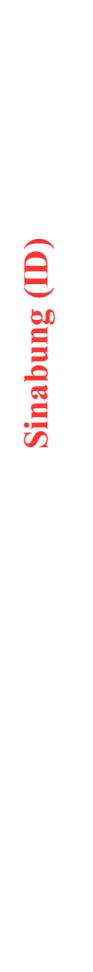 } & \#1 & Many & Many & Many & Many & Sanbesan (JP) & $\begin{array}{l}\text { San José } \\
\text { (CL-AR) }\end{array}$ & $\begin{array}{l}\text { Hunga Tonga- } \\
\text { Hunga Ha'apa } \\
\text { (TO) }[5]\end{array}$ & Matutum (PH) \\
\hline & \#2 & Many & Many & Many & Many & Nijima (JP) & $\begin{array}{c}\text { San Pedro- } \\
\text { San Pablo (CL) }\end{array}$ & Niijima (JP) [2] & Little Sitkin (US) \\
\hline & $\# 3$ & Many & Many & Many & Many & Rausudake (JP) & $\begin{array}{c}\text { Tandikat- } \\
\text { Singgalang (ID) }\end{array}$ & Victory (PG) [1] & Atacazo (EC) \\
\hline & \#4 & Many & Many & Many & Many & Loloru (PG) & Peuet Sague (ID) & $\begin{array}{l}\text { Suretamatai } \\
\text { (VU) [3] }\end{array}$ & $\begin{array}{c}\text { San Pedro-San } \\
\text { Pablo (CL) }\end{array}$ \\
\hline & \#5 & Many & Many & Many & Many & Kuchinoshima (JP) & Chiginagak (US) & $\begin{array}{l}\text { Tomariyama/ } \\
\text { Golovnin } \\
\text { (JP/RU) [1] }\end{array}$ & Acamarachi (CL) \\
\hline & \#6 & Many & Many & Many & Many & $\begin{array}{c}\text { Nevados Ojos } \\
\text { del Salado } \\
\text { (CL-AR) }\end{array}$ & Kerinci (ID) & Egon (ID) [5] & $\begin{array}{l}\text { San José } \\
\text { (CL-AR) }\end{array}$ \\
\hline & \#7 & Many & Many & Many & Many & Atacazo (EC) & Sabancaya (PE) & Callaqui (CL) [2] & $\begin{array}{c}\text { Tandikat- } \\
\text { Singgalang (ID) }\end{array}$ \\
\hline & $\# 8$ & Many & Many & Many & Many & Tacaná (MX-GT) & Turrialba (CR) & Sundoro (ID) [9] & Zimina (RU) \\
\hline & \#9 & Many & Many & Many & Many & $\begin{array}{c}\text { Hunga Tonga- } \\
\text { Hunga Ha'apa } \\
\text { (TO) }\end{array}$ & $\begin{array}{c}\text { Zhupanovsky } \\
\text { (RU) }\end{array}$ & $\begin{array}{l}\text { Miravalles } \\
(\mathrm{CR})[1]\end{array}$ & Dutton (US) \\
\hline & $\# 10$ & Many & Many & Many & Many & Iraya $(\mathrm{PH})$ & $\begin{array}{c}\text { Guagua } \\
\text { Pichincha (EC) }\end{array}$ & $\begin{array}{l}\text { Peuet Sague } \\
\text { (ID) [7] }\end{array}$ & $\begin{array}{l}\text { Nevado del Ruiz } \\
\text { (CO) }\end{array}$ \\
\hline
\end{tabular}

Black bold text: analogue volcanoes ranked top 10 by scheme A. Blue bold text: analogue volcanoes ranked top 10 by scheme B. Red bold text: analogue volcanoes ranked top 10 by scheme C. Blue-background cell: analogue volcanoes ranked top 10 by schemes A\&B. Red-background cell: analogue volcanoes ranked top 10 by schemes A\&C. Black-background cell: analogue volcanoes ranked top 10 by all the weighting schemes

The spatial distribution of the top 20 analogue volcanoes to Kîlauea, according to the three weighting schemes is displayed in Fig. 5a-c. The vast majority of analogues from schemes A (20/20) and B (13/20) are located either on intraplate settings, such as oceanic islands (e.g. Galapagos, Comoros) or on rift zones (e.g. Iceland, East African Rift). This spatial clustering of volcanoes away from subduction zones is a nonrandom pattern. Approximately $70 \%$ of the volcanoes in the GVP database are located on subduction zones. Therefore, if 20 volcanoes were sampled at random, 14 volcanoes would be located, on average, on subduction zones. This number is significantly above the number of analogue volcanoes obtained for Kīlauea in schemes A and $\mathrm{B}$. In scheme $\mathrm{C}$, the analogue volcanoes are more dispersed spatially and they can also occur on subduction zones (Fig. $5 \mathrm{c}$ ). These volcanoes are purely basaltic stratovolcanoes on the western rim of the Pacific plate and whose values of $M$ are slightly above the mean value for complex stratovolcanoes and therefore closer to the mean value of shield volcanoes (Table 3 ).
Kîlauea is a below-average shield volcano in terms of morphology $(M=0.447$; Table 3$)$. Therefore, a greater proportion of stratovolcanoes will have $M$ values similar to Kîlauea, compared with other shield volcanoes with higher $M$ values (see Fig. 2c).

\section{Fuego, Guatemala}

Fuego is a basaltic-andesitic stratovolcano related to the subduction of the Cocos plate under the Caribbean plate and forms part of a lineament of volcanic centres that includes the mainly Pleistocene Meseta volcano and Fuego's twin volcano: Acatenango (Rose et al. 1978; Chesner and Rose 1984; Chesner and Halsor 1997). Volcanism has migrated spatially, from north to south, and chemically, from andesitic to basaltic compositions, with time (Chesner and Rose 1984). Historical volcanic activity has been mostly sourced from Fuego and has predominantly consisted of open-conduit, persistent, and frequent explosive activity (from Strombolian to Vulcanian) punctuated by larger eruptions up to sub-Plinian (Rose et al. 
Kīlauea (USA)
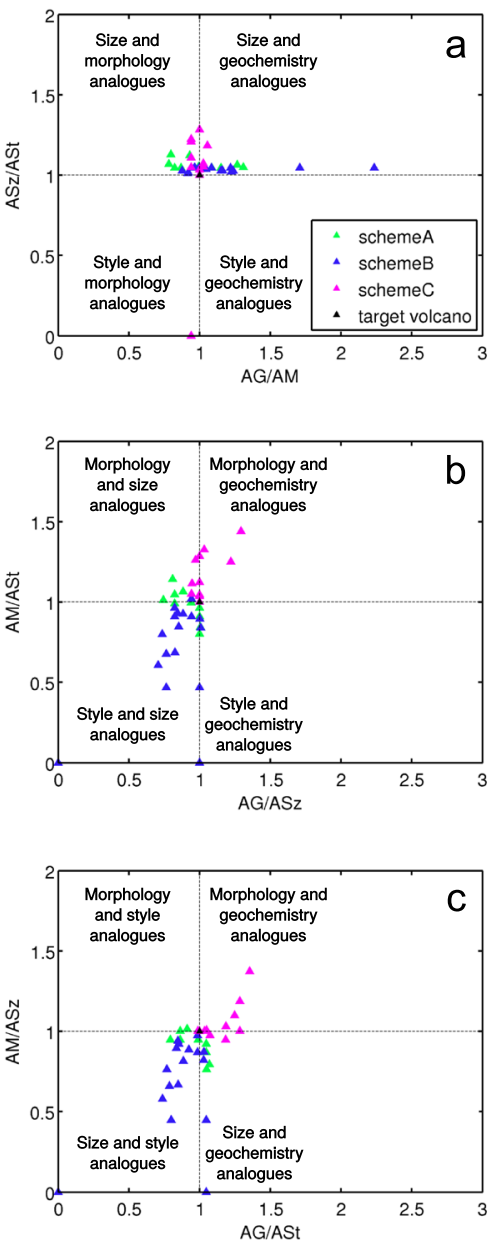

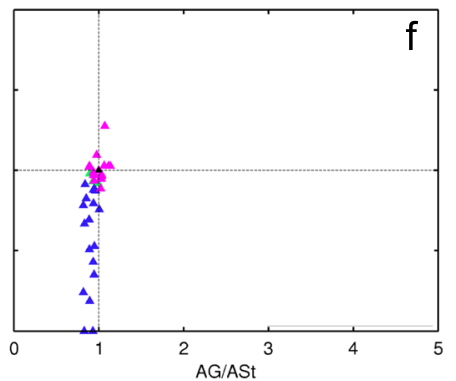

Sinabung (Indonesia)
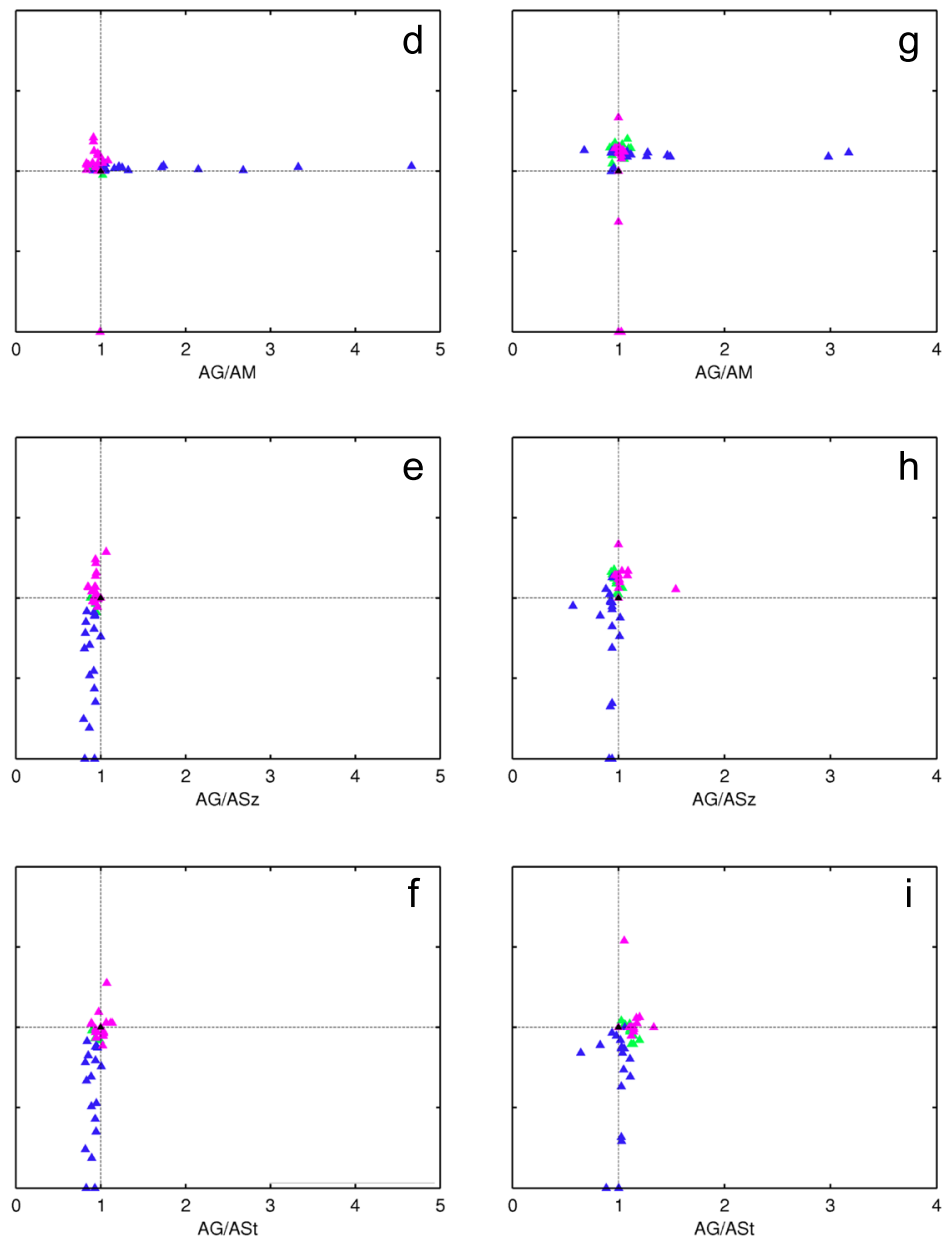

Fig. 4 Ratios between single-criterion volcano analogies for the top 20 analogue volcanoes to Kîlauea, USA (a-c); Fuego, Guatemala (d-f); and Sinabung, Indonesia (g-i), according to three different weighting schemes to calculate multi-criteria volcano analogies: all criteria, equalweight (scheme A); eruption size and style only (scheme B); and rock geochemistry and volcano morphology only (scheme C). Note that, even if a given weighting scheme uses only two criteria (e.g. scheme B), the

\section{8; Martin and Rose 1981; Lyons et al. 2010; Naismith} et al. 2019).

Tectonic setting is a non-differentiating criterion for a subduction-zone volcano like Fuego. All the other single criteria can be used to identify a set of top 10 analogue volcanoes to Fuego (Table 5). Those analogues according to volcano morphology are perfect analogues because Fuego is one of the 11 volcanoes in the morphological database with a value of $M=0$. These volcanoes have very high values of $H$ and $H / W^{*}$ and, at the same time, very small values of $T$ and $d$. The top 10 eruption-style analogue volcanoes (Table 5) produce ballistics and tephra, and lava flows and/or fountaining on $98 \%$ and over $30 \%$ of their eruptions, on average. Watersediment flows and PDCs are generated, respectively, in $11 \%$ and $13 \%$ of their eruptions, on average. Finally, the average percentage of eruptions with collapse/destruction of the identified analogue volcanoes can have data for all the analogy criteria and, thus, the analogy ratios can be calculated for any of these criteria. The different quadrants in the graphs show which criteria are dominant in the process of identifying analogue volcanoes to the specific target volcano. ATs: analogy in tectonic setting; AG: analogy in rock geochemistry; AM: analogy in volcano morphology; ASz: analogy in eruption size; ASt: analogy in eruption style

edifice or with caldera formation is $0.6 \%$ and $0.3 \%$, respectively.

The top 10 analogue volcanoes according to scheme A tend to be related to volcanoes with high values in analogy morphology or eruption style (Table 5). In scheme B, the top 10 analogue volcanoes tend to appear in the top 10 list of eruption style analogues as well. However, their analogy in eruption size is also high, because their ASz/ASt ratio is very close to 1 (Fig. 4d). The values of multi-criteria analogy in scheme $\mathrm{C}$ seem to be closely linked with high values of analogy in morphology while none of the rock-geochemistry top 10 analogue volcanoes appears in the lists from scheme A, B or C (Table 5). Nevertheless, the analogy in geochemistry seems to be better coupled with the analogy in eruption size and style as it is shown by the analogue volcanoes for scheme B in Fig. $4 \mathrm{e}, \mathrm{f}$. The large scatter in the values of the ratios that involve 

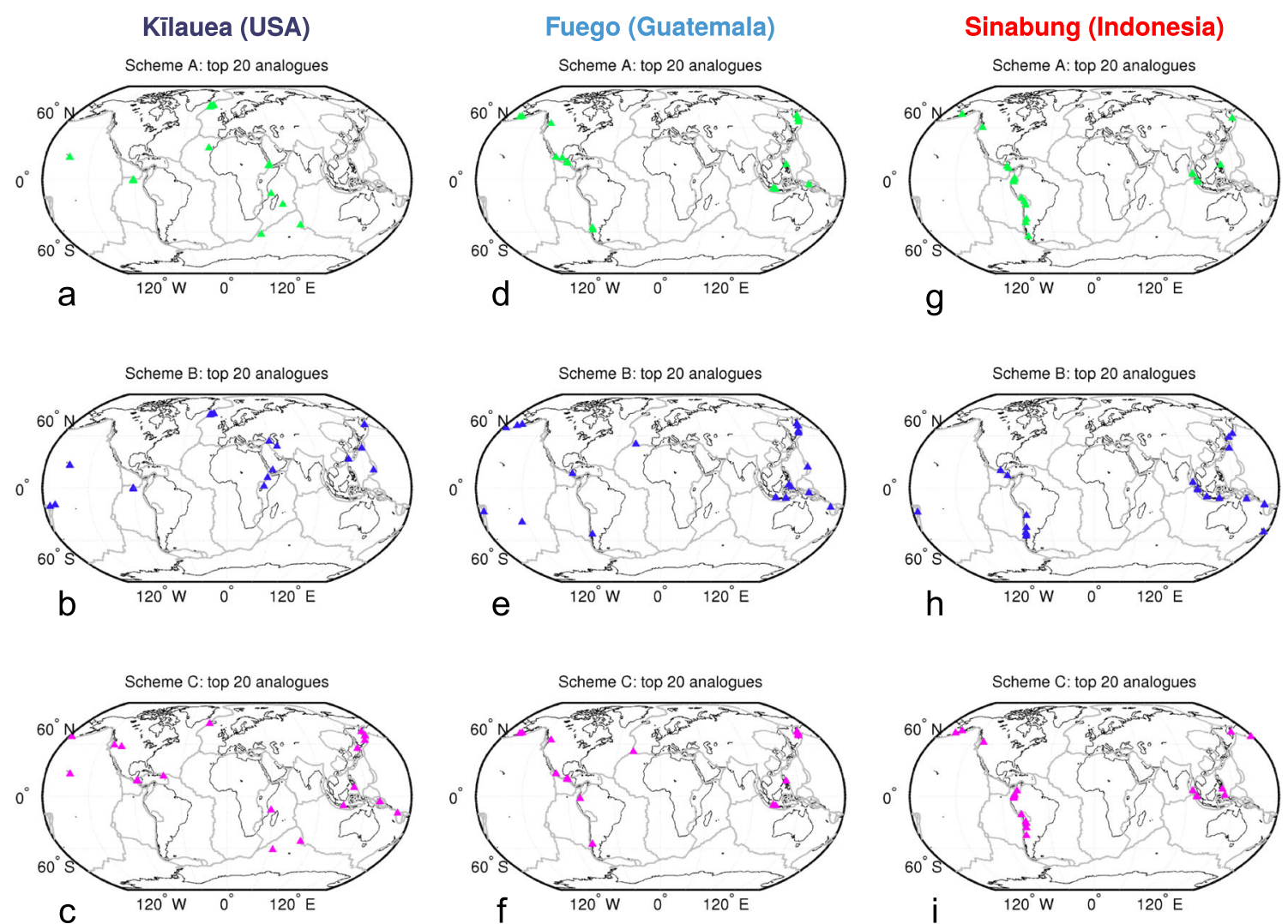

Fig. 5 Spatial distribution of the top 20 analogue volcanoes to Kîlauea, USA (a-c); Fuego, Guatemala (d-f); and Sinabung, Indonesia (g-i), according to the multi-criteria analogy metrics calculated via three different weighting schemes. Plate boundaries taken from Bird (2003)

the analogy in morphology suggests that volcanoes that have eruption sizes and styles similar to Fuego do not have particularly similar morphologies. Somewhat equivalently, the analogue volcanoes for scheme $\mathrm{C}$ show a greater scatter along the AM/ASt ratio (y-axis, Fig. 4e) than along the AG/ASt ratio ( $x$-axis, Fig. 4f): that is, volcanoes with morphologies similar to Fuego have more varied eruption styles, compared with Fuego than volcanoes with rock geochemistries similar to Fuego. Three volcanoes are listed in two different schemes: Tacaná and Merbabu (schemes A, C; the latter is not top 10 in any single-criterion search) and Pavlof (schemes A, B); and two volcanoes are listed in all three weighting schemes: Semeru and Klyuchevskoy.

Spatially, the analogue volcanoes to Fuego are located on subduction zones, independently of whether tectonic setting is used (scheme A) or not (schemes B and C) as a search criterion (Fig. $5 \mathrm{~d}-\mathrm{f}$ ). These spatial distributions are also nonrandom because the number of volcanoes on subduction zones (from 18 to 20) is significantly higher that what could be expected, on average, if the locations of 20 volcanoes were randomly sampled from the GVP database. The analogue volcanoes in schemes A and B are relatively evenly distributed along the western coast of the American continents, the western edge of the Pacific plate (especially in scheme B) and
Indonesia. In scheme $\mathrm{C}$, half of the top 10 analogue volcanoes are located in Kamchatka, Russia.

\section{Sinabung, Indonesia}

Sinabung is an andesitic-to-dacitic stratovolcano related to the oblique subduction of the Indo-Australian plate under the Eurasian plate along the island of Sumatra (Diament et al. 1992), and it is located less than $40 \mathrm{~km}$ away from the north-western edge of Lake Toba caldera. Volcanic activity at Sinabung was relatively unknown, and had been absent for the last 400 years, before its first historical eruption occurred in 2010 (Gunawan et al. 2019). After 3 years of repose, the volcano again erupted in 2013, this time evolving into a long-term ( $\sim 5$ years) eruption, which included initial phreatic and phreatomagmatic phases, several periods of lava-dome growth and collapse, andesitic lava flows and (cyclic) Vulcanian explosions (Gunawan et al. 2019; Nakada et al. 2019; Pallister et al. 2019).

In general, single-criterion searches are extremely uninformative for Sinabung because it has an ID profile (Fig. 3) that is very similar to many other volcanoes in the databases, when looking at single-criterion analogy only. For instance, there are hundreds of volcanoes on a subduction zone under continental crust and many tens of volcanoes with rock 
geochemistry evenly distributed between andesite and dacite. The only single criterion that provides a list of top 10 analogue volcanoes to Sinabung is eruption style (Table 5).

Multi-criteria searches bring much more information because the number of volcanoes that share the very same characteristics to the target volcano, for several single criteria, is much lower. The analogue volcanoes according to scheme A arise from a combination of all the criteria and they are all different from the list of analogue volcanoes obtained from the analogy in eruption style. They display a relatively clustered pattern (with some outliers) around the $(1,1)$ point according to different ratios between single criteria (Fig. 4g-i), which suggests that the values of all single-criterion analogies are comparable. These top 10 scheme-A analogue volcanoes (Table 5) show the following characteristics: (i) they all are on subduction zones under continental crust; (ii) their expected geochemistry is predominantly andesitic to dacitic; (iii) they have morphologies significantly below the average morphology of stratovolcanoes (mean value on $M=0.172$ ); (iv) their averaged distribution of eruption sizes is dominated by $\mathrm{VEI} \leq$ 2 eruptions but VEI $3+$ eruptions have non-negligible probabilities of occurrence (8\%, in particular); and (v) their averaged hazardous phenomenology indicates that relatively few eruptions would produce lava flows and/or fountaining (4\%), water-sediment flows $(2 \%)$ or PDCs $(9 \%)$. The latter is in stark contrast with the eruption-style profile of Sinabung, especially for PDCs, which have been reported in $67 \%$ of the eruptions. Nevertheless, the eruption data for Sinabung is strongly deficient, with only two eruptions with a VEI size assigned and three eruptions with hazardous phenomena recorded in the GVP database (and no reference to phreatic/ phreatomagmatic activity or lava flows for the 2013-2018 eruption; GVP 2013). This potential issue is tackled in the next section.

The set of top 10 analogue volcanoes from scheme B includes some of the volcanoes identified with the singlecriterion search of analogy in eruption style. Still, the majority of multi-criteria analogue volcanoes are not listed in the single-criterion search (Table 5). The analogue volcanoes from scheme $\mathrm{C}$ are also different from the single-criterion analogues, apart from the case of Atacazo (Table 5). This volcano is a perfect analogue according to tectonic setting, rock geochemistry and morphology and a top 10 analogue in terms of eruption style.

In terms of the spatial distribution, the analogue volcanoes to Sinabung are always located on subduction zones, independently of whether tectonic setting is used as analogy criterion or not. As in the case of Fuego volcano, this represents a nonrandom spatial distribution. These analogues are distributed similarly in schemes A and C (Fig. 5g, i), with the western coast of South America and Indonesia dominating over other areas (10 out of 17 different analogue volcanoes are located there). Among them, three volcanoes appear as top 10 analogue volcanoes according to both scheme A and C: San José, San Pedro-San Pablo and Tandikat-Singgalang. In scheme B (Fig. 5h), the analogue volcanoes to Sinabung appear to be more scattered and on different areas compared to schemes A and C. Some of these analogue volcanoes may not be fully representative because of the issues with the eruption data for Sinabung explained before.

Interestingly, the distribution of VEI sizes for Kîlauea (for which tens of eruptions are recorded in the GVP database) is almost identical to the (incomplete) distribution for Sinabung (Fig. 3c). Therefore, the differences observed in the sets of analogue volcanoes to Kīlauea and Sinabung using scheme B (Fig. 5b, h) can only be explained in terms of eruption style. Even though the eruption-style data for Sinabung are also incomplete, the hazardous phenomenology recorded at the two volcanoes is remarkably disparate (Fig. 3d). Thus, Kilauea shows the typical profile of a lava-flow-producing volcano while Sinabung can be ascribed to the profile of a tephra-and-PDC-producing volcano. Accordingly, the analogue volcanoes to Kîlauea and Sinabung derived from scheme B are still fundamentally different in terms of tectonic setting (Fig. 5b, h), rock geochemistry and even morphology (e.g. mean $(M)=0.541$ for the Kîlauea analogues and mean $(M)$ $=0.298$ for the Sinabung analogues).

\section{Discussion}

\section{Volcanic hazard assessment}

VOLCANS represents a new objective method for identifying sets of analogue volcanoes, for a given volcano of interest, using global volcanological databases. This type of automated and flexible procedure to extract sets of analogue volcanoes has the potential to become a fundamental tool used to inform volcanic hazard assessments, during quiescent, unrest and crisis phases. Existing methods and tools such as (Bayesian) event trees (Newhall and Hoblitt 2002; Marzocchi et al. 2008, 2010; Newhall and Pallister 2015), Bayesian Belief Networks (Aspinall et al. 2002; Hincks et al. 2014; Tierz et al. 2017) or hierarchical Bayesian modelling (Ogburn et al. 2016) would extremely benefit from deriving its prior distributions from objective sets of analogue volcanoes (Sheldrake 2014; Biass et al. 2016). Similarly, alternative parameterisations of the hazard models could be built from different sets of analogue volcanoes and this could be used to quantify the epistemic uncertainty and/or for testing of hazard models (e.g. Marzocchi and Jordan 2014; Spiller et al. 2014; Tierz et al. 2016a, 2016b). The presented method can also be used to enlarge the datasets used in the hazard assessment. Up to now, the common practice has been to use data from a limited set of best analogue volcanoes to assess volcanic hazard (e.g. Marzocchi et al. 2004; Sandri et al. 2012; 
Tierz et al. 2016a; Wright et al. 2019). With VOLCANS, the hazard analyst could expand the dataset to any available volcano and weigh the data according to the multi-criteria analogy calculated between these volcanoes and the target volcano. In this way, data from good analogues would count more than data from other volcanoes. This would dramatically increase the amount of data available for the hazard assessment, hence, improving the robustness of the statistics computed (e.g. Newhall and Hoblitt 2002; Marzocchi et al. 2008, 2010; Ogburn et al. 2016). Still, if selecting the best analogue volcanoes is the preferred strategy for the hazard analysis, VOLCANS can also help define such a set: e.g. top 10, top 20 , volcanoes above a given threshold of volcano analogy. Volcano analogy can be computed using any possible multicriteria weighting scheme, depending on the particular needs and requirements of the user of the method. This flexibility helps with adaptation and application to different situations and volcanological problems. Nonetheless, there will always be the need to assess the significance of the analogue sets found independently (Newhall et al. 2017) as well as to supplement the results with relevant expert scientific knowledge not available in the databases (Aspinall et al. 2002, 2003; Selva et al. 2012; Hincks et al. 2014; Newhall and Pallister 2015).

\section{A tool to complement expert-derived analogue volcanoes}

The hazard analyst/team may also be interested in assessing the general appropriateness of sets of analogue volcanoes that were selected, a priori, during previous crises and/or hazard evaluations (e.g. Marzocchi et al. 2004; Sandri et al. 2012; Newhall and Pallister 2015). Here, this is exemplified by looking at the values of multi-criteria analogy calculated for volcanoes that have been taken as analogues to the three example volcanoes by previous published and unpublished studies. In particular: Piton de la Fournaise (France) and Etna (Italy) for Kîlauea (Peltier et al. 2015; Poland et al. 2017); Villarrica, Llaima (Chile), Pacaya (Guatemala), Reventador and Tungurahua (Ecuador) for Fuego (Eliza Calder, unpublished data); and Unzen (Japan), Soufrière Hills (Montserrat), Nevado del Huila (Colombia), Guagua Pichincha (Ecuador) and Redoubt (USA) for Sinabung (Heather Wright, pers. comm., October 12, 2018).

For all three volcanoes, the multi-criteria analogy values and the percentage of volcanoes in the GVP database that are better analogues than the selected a priori analogues are analysed. This percentage can be calculated as follows: (1) for each target volcano and weighting scheme, a value of multicriteria analogy can be calculated between the target volcano and any volcano in the GVP database; (2) the value of multicriteria analogy for a given a priori analogue volcano corresponds with a specific percentile of the distribution of all multi-criteria analogy values; (3) one minus this percentile provides the percentage of better analogues (i.e. those with higher multi-criteria analogy than the a priori analogue). Additionally, and in the case of Fuego, an analysis on how sensitive the results of VOLCANS are to changes in the eruptive record of the target volcano has been carried out. This analysis shows that the method is quite stable even when adding or removing up to 15 eruptions from this eruptive record (see Online Resources 7 and 8).

\section{Kilauea, USA}

The highest multi-criteria analogy occurs between Kīlauea and Piton de la Fournaise, independently of the weighting scheme used (Fig. 6a). For instance, their morphology is quite similar (Kīlauea, $M=0.447$; Piton de la Fournaise, $M=$ 0.395), even though Kîlauea is volumetrically one order of magnitude larger than Piton de la Fournaise (Peltier et al. 2015). This could be related to geochemistry and/or eruption style: e.g. their edifices are principally built from lava flows, with low proportions of pyroclastic material (de Silva and Lindsay 2015). In the case of Etna, several reasons account for its lack of similarity with Kîlauea. For example, the rock types in the GVP database capture the predominantly alkaline products of Etna (Correale et al. 2014; Corsaro and Métrich 2016) and this clearly separates this volcano from the tholeiitic-dominated Kīlauea and Piton de la Fournaise (Clague and Dalrymple 1987; Albarède et al. 1997). Considering the three volcanoes, eruption size and style are the criteria that better match across them (Fig. 6a). Significantly, all three volcanoes are reported to have produced tsunamis, something that is coherent with their longterm flank instability (Poland et al. 2017).

The percentages of better analogues significantly change across the different multi-criteria weighting schemes, highlighting the fact that some volcanoes can be good analogues in terms of some criteria but not according to others (Sheldrake 2014; Newhall et al. 2017). For instance, Etna may be a relatively good analogue in terms of eruption size and style, i.e. less than $10 \%$ of the Holocene volcanoes are better analogues. However, in terms of morphology and geochemistry, more than half of the Holocene volcanoes are better analogues to Kỉlauea than Etna (Fig. 6b).

\section{Fuego, Guatemala}

The best a priori analogue volcanoes to Fuego are Villarrica and Llaima, in Chile, regardless of the weighting scheme used (Fig. 6c). Geochemistry and, especially, morphology play a significant role in this as it is observed by the lower percentages of volcanoes that are better analogues than these two when scheme $\mathrm{C}$ is considered (Fig. 6d). Pacaya and Tungurahua display opposite patterns: the former is the best 


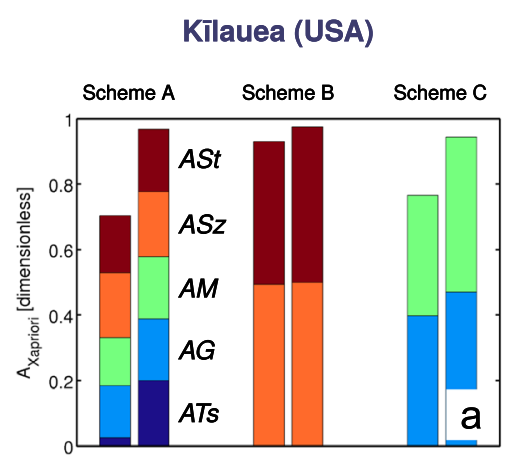

Fuego (Guatemala)
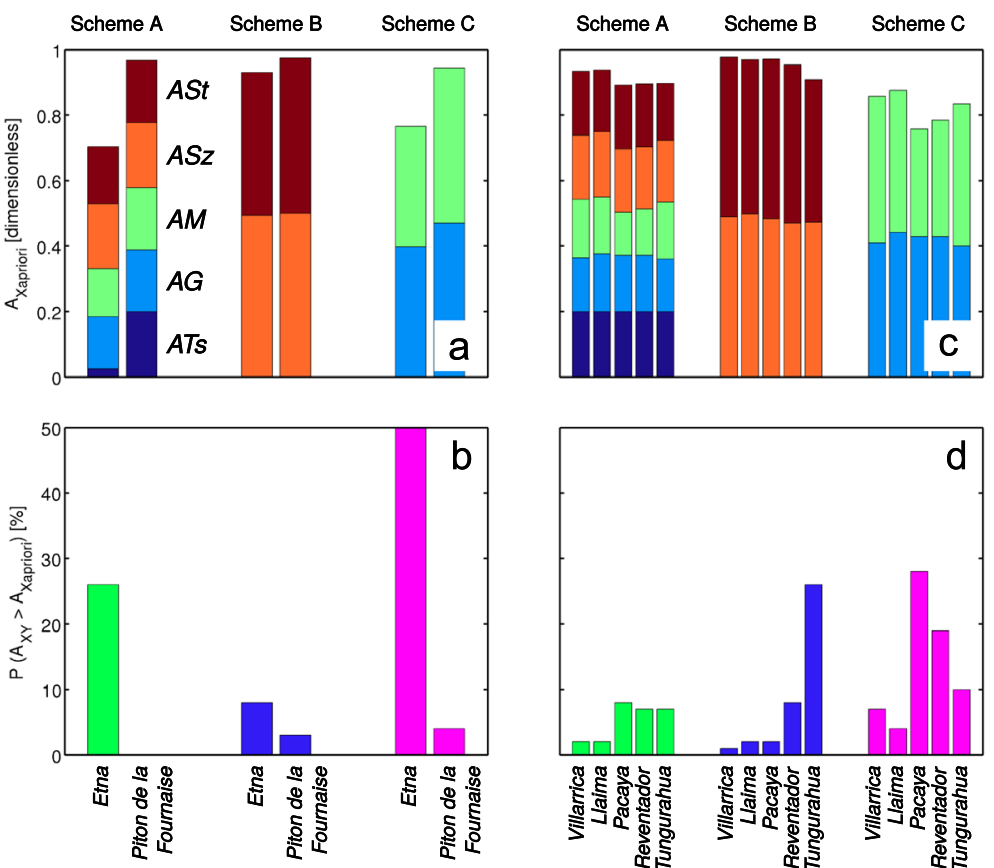

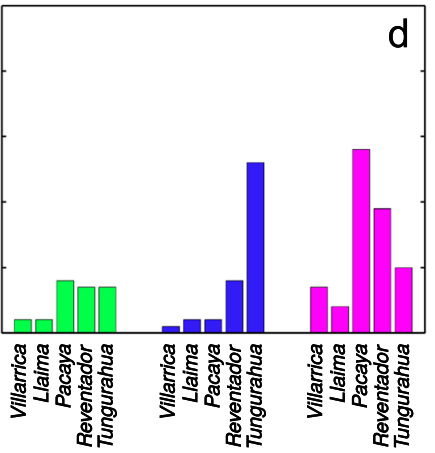

Sinabung (Indonesia)
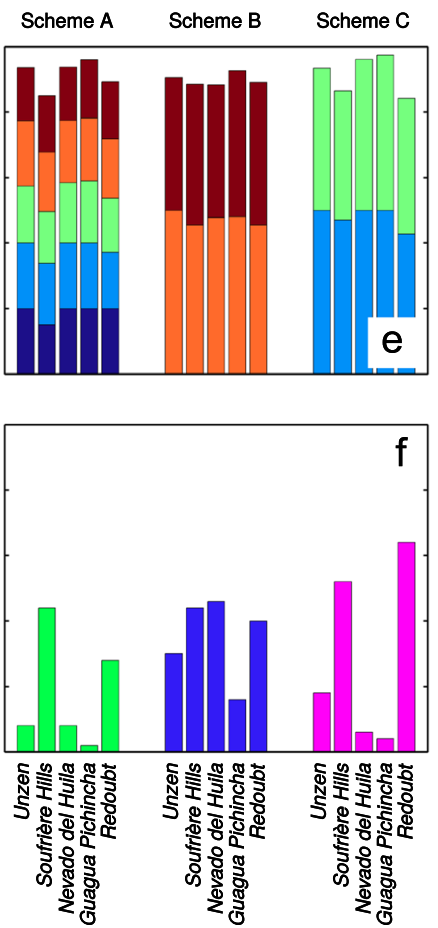

Fig. 6 Quantitative assessment of some volcanoes thought to be good analogues, a priori, to the three example target volcanoes. a, c, e: values of multi-criteria volcano analogy ( $\mathrm{A}_{\text {Xapriori }}$, where $\mathrm{X}$ denotes the example volcano) according to three different weighting schemes. The contribution of each single criterion to the total analogy is shown by the different colours (abbreviations as in Fig. 4). b, d, f: exceedance probability of
A Xapriori, calculated from the distribution of multi-criteria volcano analogy values $\left(\mathrm{A}_{\mathrm{XY}}\right)$ between each example volcano, $\mathrm{X}$, and any volcano $\mathrm{Y}$ in the GVP database. This probability can be understood as the percentage of all the volcanoes in the GVP database that are better analogues than each of the a priori analogue volcanoes, according to three different weighting schemes analogue after Villarrica and Llaima according to scheme B and the latter is the best analogue after those two according to scheme C. However, Pacaya is the least analogous to Fuego according to scheme $\mathrm{C}$ and Tungurahua is the least analogous according to scheme B (Fig. 6d). This would reinforce the decoupling between morphology (and maybe geochemistry) and eruption size and style observed for the top 20 analogues of Fuego in Fig. 4e, f. Further research would be required to understand this pattern.

\section{Sinabung, Indonesia}

The best analogue to Sinabung volcano, when taking into account all the criteria, is Guagua Pichincha, followed by Nevado del Huila and Unzen (Fig. 6e). Only 1 to $4 \%$ of the Holocene volcanoes are better analogues, according to the GVP data (Fig. 6f). Interestingly, Nevado del Huila is the least analogous of the five selected a priori analogue volcanoes when eruption size and style are evaluated (scheme B). Soufrière Hills and Redoubt are not particularly good analogues because their morphologies are more complex (i.e. larger $M$ values) and because their rock types are not exclusively andesites and dacites. Also eruption-style data plays a role in the volcano analogy but the data for Sinabung are not properly recorded in the version of the GVP database used in this analysis. That is, no lava flows or water-sediment flows are reported in the ID profile (Fig. 3) even though they did occur during the 2013-2018 eruption (Gunawan et al. 2019; Nakada et al. 2019).

To test how the values of volcano analogy may vary if the profile of Sinabung is modified, the following changes are applied: (1) lava flows and lahars from the 2013-2018 eruption are included; and (2) the 2013-2018 eruption is updated to VEI 4 (GVP, 2013, database version 4.7.4). Results are very stable for scheme A, even for the percentage of better analogues (maximum change of $2 \%$, Fig. 7). This is partly due to the eruption size and style having a combined weight of $40 \%$ in the calculation of the multi-criteria analogy. Obviously, scheme $\mathrm{B}$ is the one that changes the most and the differences in percentage of better analogues can be up to $11 \%$. The result of updating Sinabung's profile is that of systematically reducing the percentage of better analogue volcanoes, with the exception of Redoubt. This decrease in the percentage can be explained by the fact that there are many more volcanoes in the GVP database with distributions of eruption sizes very dominated by VEI $\leq 2$ eruptions (Sinabung's GVP 4.6.7 profile) than volcanoes with distributions with substantial frequency of VEI 4 eruptions (Sinabung's GVP 4.7 .4 profile). 
Fig. 7 Comparison between the values of multi-criteria volcano analogy, $\mathrm{A}_{\text {Xapriori }}$, and the values of exceedance probability of $\mathrm{A}_{\text {Xapriori, }}$, for the a priori analogue volcanoes to Sinabung $(\mathrm{H}$. Wright, pers. comm., October 12, 2018) when using two different ID profiles for the target volcano. a, b: ID profile stored in the GVP database, version 4.6.7 (see Fig. 3 ); c, d: ID profile obtained after upgrading the 2013-2018 to VEI 4 and adding lava flows and lahars as phenomenology that happened during the aformentioned eruption (Gunawan et al., 2019; Nakada et al., 2019; GVP database, version 4.7.4)
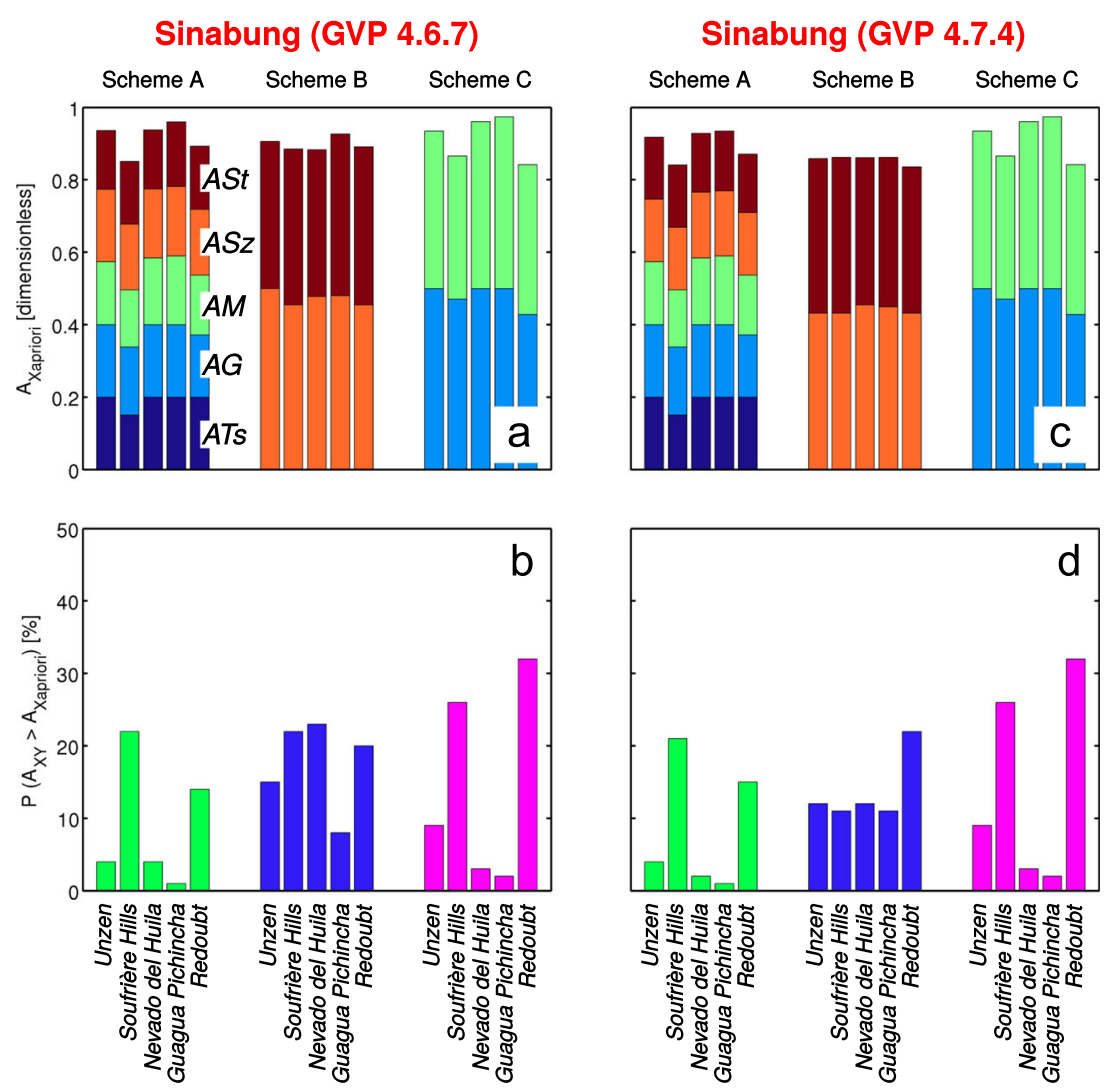

Therefore, the updated profile makes the a priori analogues to be more unique analogues of Sinabung.

\section{Commonalities in unique volcanoes}

The presented method can also be applied to investigate commonalities in unique volcanic systems (Cashman and Biggs 2014), thus aiding research on how volcanoes work. For example, if two or more data-poor volcanoes are identified to be good general analogues to each other, further research on one of them may serve to (1) ensure this volcano analogy holds when more data are collected, and (2) use the data from one of the volcanoes as proxy for the other volcano. This research may be guided by prioritising research on volcanoes that seem to be analogues to one or more high-relevance volcanoes (e.g. persistently active volcanoes with seasonal lahar activity: Fuego and Semeru; Lyons et al. 2010; Thouret et al. 2014). Other findings of analogue volcanoes can also provide hints about magmatic or physical volcanic processes. Further dedicated research could be targeted at exploring and understanding some general observations derived from VOLCANS. For instance, analogue volcanoes to Kîlauea are located on oceanic islands or rifting settings when all the criteria are used (scheme A, Fig. 5a) but can also be found on subduction zones when morphology and rock geochemistry are the only criteria used (scheme C, Fig. 5c). In the case of Fuego, only subduction-zone volcanoes are top 20 analogues when using all criteria but one oceanic-island volcano (Pico, Azores) appears when using morphology and geochemistry (Fig. 5d, f). On the contrary, all analogue volcanoes to Sinabung are located on subduction zones, independently of the criteria used (Fig. 5f-i). Given that primary (mantle) magmas are exclusively of basaltic composition (Rogers 2015), the latter type of volcanism can occur on any tectonic setting (and probably type of volcano) while more silicic volcanism is restricted to areas where magma ascends slowly and/or stagnates and, thus, crustal anatexis, magma differentiation (and segregation) and/ or crustal assimilation are promoted (Annen et al. 2005; Bachmann et al. 2007; Hutchison et al. 2018). Also, Kîlauea's morphology, expressed as its $M$ value, is similar to many volcanoes in the databases (Figs. 2c, 3a) and, therefore, those volcanoes may occur in varied tectonic settings (Fig. 5c). On the contrary, the very-low $M$ values of Fuego and Sinabung are shared by fewer volcanoes in the databases (Figs. 2c, 3a) and those tend to be restricted to subductionzone settings, where magmatic conditions and volcanic processes favour the development of such morphologies (Grosse et al. 2009; de Silva and Lindsay 2015).

\section{Analogue volcanoes and global datasets}

Tectonic setting, rock geochemistry and morphology may be more stable criteria than eruption size and style to search for general analogues, unless there are profound changes like 
those in morphology linked with the partial or total destruction of the edifice (Cioni et al. 1999; Belousov et al. 2007). Eruption size and style data will depend more strongly on under-recording (Mead and Magill 2014; Sheldrake 2014; Rougier et al. 2016), under-/mis-reporting and data discovery (Loughlin et al. 2015). Emphasis should be placed on thoroughly double-checking the inclusion of unequivocal data for all relevant hazardous phenomena occurring during a given eruption, from reports released by volcano observatories. Reporting itself should also ensure that the occurrence of all hazardous phenomena is properly recorded. Moreover, the importance of using a standardised (multilingual) nomenclature in reporting eruptive phenomena must be re-assessed, to circumvent some of the difficulties that using the available data currently implies. For example, the term "caldera collapse" can be equally used to describe purely effusive or VEI 7+ eruptions (Branney and Acocella 2015; Gudmundsson et al. 2016). In spite of the aforementioned issues, VOLCANS is a flexible tool that allows the user to give different weights to each criteria to decrease the influence of inaccurate data, for instance. It also permits rapid updating of the volcano ID profiles and, hence, re-calculation of volcano analogies as new data become available (Fig. 7).

\section{Conclusions}

We present the VOLCano ANalogues Search tool (VOLCANS), an approach with which to explore and quantify the similarity between volcanic systems at a global scale by making use of three separate volcanological databases. The key outcome of the method is the objective (i.e. data-driven), structured and reproducible quantification of the degree of volcano analogy among any two volcanic systems listed in the Global Volcanism Program database. This approach can be used to derive informative sets of analogue volcanoes and/ or to evaluate the appropriateness of volcanoes selected as analogues through other means, e.g. expert judgement. The application of VOLCANS is illustrated for three different volcanoes with significant recent or ongoing eruptions (Kīlauea, USA; Fuego, Guatemala; and Sinabung, Indonesia). Specifically, we find that:

i. Analogy in volcano morphology can be fully quantified by using simplified variables for dimensions of volcanic edifices: a continuum in morphologies arises from the datasets (Grosse et al. 2014), but different types of volcano have values of a unified morphological variable that follow different probability distributions;

ii. Depending on the characteristics of the target volcano, some criteria may be non-differentiating, that is: they are not effective differentiators of small sets of analogue volcanoes because there are too many volcanoes with similar characteristics. Whether a particular analogy criterion is non-differentiating, varies on a volcano to volcano basis;

iii. Sets of analogue volcanoes identified from multi-criteria searches can include, as top analogues, volcanoes that are not included in the sets of top analogues identified using only single-criterion analogy metrics;

iv. Plausible sets of analogue volcanoes can be obtained using as little as two criteria (e.g. eruption size and style, scheme B), even in cases where data for one of the criteria could be suspected as being deficient (e.g. eruption size for Sinabung), provided that data for the other criteria encode effective differentiators. For example, sets of analogue volcanoes for Sinabung and Kïlauea in scheme B are differentiated mostly because of the frequent generation of PDCs at Sinabung compared with Kīlauea. In general, analogue searches using more than one analogy criterion provide quite stable results of VOLCANS;

v. The spatial distributions of top analogue volcanoes follow non-random patterns even when tectonic setting is not used as a criterion for volcano analogy. For instance, at least 38 out of 40 analogue volcanoes to Fuego and Sinabung are located on subduction zones when using eruption size and style only (scheme B) and rock geochemistry and volcano morphology only (scheme C) as the analogy criteria;

vi. The degree of decoupling between different criteria of volcano analogy can be assessed through the dispersion in the ratios of single-criterion analogy metrics, when using different multi-criteria weighting schemes: the more similar the ratios for different schemes (i.e. the more clustered), the more coupled the analogy criteria.

Future applications of VOLCANS may be targeted at gaining a better understanding of the similarities and differences between volcanic systems and/or at improving volcanic hazard assessment, especially for those volcanoes that are data-poor.

Acknowledgements We earnestly thank Sébastian Biass and an anonymous reviewer for their thorough reviews and Christopher Gregg for his extremely valuable comments and editorial handling. All the input received helped us improve the clarity and quality of the manuscript substantially. We sincerely thank Benjamin Andrews and Edward Venzke for assistance in the use and content of the GVP database; and Heather Wright for kindly sharing her knowledge about analogue volcanoes of Sinabung and for valuable discussions. Finally, we would like to warmly thank many colleagues with whom we have shared fruitful discussions about volcanic systems, their analogies and dissimilarities: Sarah Ogburn, Susanna Jenkins, Ben Clarke, Charlotte Vye-Brown, Sam Engwell, Julia Crummy, Max Van Wyk de Vries, Luigi Passarelli, Laura Sandri, Isabel Marín, Teresa Ubide, David Pyle, Fabien Albino, Matthieu Kervyn, Elaine Spiller, Robert Wolpert, Larry Mastin, Cynthia Gardner, Jacob Lowenstern, Wes Thelen, John Pallister, Alexa Van Eaton, Peter Kelly, Jim Vallance, John Ewert and the VDAP team and CVO as a whole. Published with permission of the Executive Director of British Geological Survey (NERC-UKRI). 
Authors' statement The data supporting the conclusions are shown in the figures and tables presented. Interested readers will find additional figures, tables, and data sets in the Electronic Supplementary Material. On request, the authors can also provide MATLAB (MATLAB, 2012) files containing more specific results or used to produce the figures.

PT, SL and EC conceived the study. PT processed the data, analysed the results, prepared the figures and wrote the manuscript, with input from the other authors. All authors read, reviewed, and approved the final version of the manuscript.

Funding information The research leading to these results has received funding from the UK Natural Environment Research Council Rift Volcanism: Past, Present and Future (RiftVolc) project (grant NE/ L013460/1)

Open Access This article is licensed under a Creative Commons Attribution 4.0 International License, which permits use, sharing, adaptation, distribution and reproduction in any medium or format, as long as you give appropriate credit to the original author(s) and the source, provide a link to the Creative Commons licence, and indicate if changes were made. The images or other third party material in this article are included in the article's Creative Commons licence, unless indicated otherwise in a credit line to the material. If material is not included in the article's Creative Commons licence and your intended use is not permitted by statutory regulation or exceeds the permitted use, you will need to obtain permission directly from the copyright holder. To view a copy of this licence, visit http://creativecommons.org/licenses/by/4.0/.

\section{References}

Acocella V, Di Lorenzo R, Newhall C, Scandone R (2015) An overview of recent (1988 to 2014) caldera unrest: knowledge and perspectives. Rev Geophys 53:896-955

Aiuppa A, Burton M, Caltabiano T, et al (2010) Unusually large magmatic $\mathrm{CO}_{2}$ gas emissions prior to a basaltic paroxysm. Geophys Res Lett 37. doi: https://doi.org/10.1029/2010GL043837

Albarède F, Luais B, Fitton G et al (1997) The geochemical regimes of Piton de la Fournaise volcano (Réunion) during the last 530000 years. J Petrol 38:171-201

Annen C, Blundy JD, Sparks RSJ (2005) The genesis of intermediate and silicic magmas in deep crustal hot zones. J Petrol 47:505-539

Aspinall WP, Loughlin SC, Michael FV et al (2002) The Montserrat Volcano Observatory: its evolution, organization, role and activities. Geol Soc Lond Mem 21:71-91

Aspinall WP, Woo G, Voight B, Baxter PJ (2003) Evidence-based volcanology: application to eruption crises. J Volcanol Geotherm Res 128:273-285

Bachmann O, Miller CF, De Silva SL (2007) The volcanic-plutonic connection as a stage for understanding crustal magmatism. J Volcanol Geotherm Res 167:1-23

Bebbington M (2008) Incorporating the eruptive history in a stochastic model for volcanic eruptions. J Volcanol Geotherm Res 175:325333. https://doi.org/10.1016/j.jvolgeores.2008.03.013

Bebbington MS (2014) Long-term forecasting of volcanic explosivity. Geophys J Int 197:1500-1515

Belousov A, Voight B, Belousova M (2007) Directed blasts and blastgenerated pyroclastic density currents: a comparison of the Bezymianny 1956, Mount St Helens 1980, and Soufrière Hills, Montserrat 1997 eruptions and deposits. Bull Volcanol 69:701-740

Bertagnini A, Métrich N, Landi P, Rosi M (2003) Stromboli volcano (Aeolian Archipelago, Italy): an open window on the deep-feeding system of a steady state basaltic volcano. J Geophys Res Solid Earth 108. doi: https://doi.org/10.1029/2002JB002146

Biass S, Bonadonna C, Connor L, Connor C (2016) TephraProb: a Matlab package for probabilistic hazard assessments of tephra fallout. J Appl Volcanol 5:10

Bird P (2003) An updated digital model of plate boundaries. Geochem Geophys Geosyst 4. doi: https://doi.org/10.1029/2001GC000252

Blackburn EA, Wilson L, Sparks RSJ (1976) Mechanisms and dynamics of strombolian activity. J Geol Soc Lond 132:429-440. https://doi. org/10.1144/gsjgs.132.4.0429

Branney M, Acocella V (2015) Calderas. In: Sigurdsson H, Houghton B, McNutt S, Rymer H, Stix J (eds) The encyclopedia of volcanoes, 2nd edn. Academic Press, Cambridge, pp 299-315

Calvari S, Spampinato L, Lodato L (2006) The 5 April 2003 vulcanian paroxysmal explosion at Stromboli volcano (Italy) from field observations and thermal data. J Volcanol Geotherm Res 149:160-175

Carey R, Cayol V, Poland M, Weis D (2015) Hawaiian volcanoes: from source to surface. John Wiley \& Sons, Hoboken

Cashman K, Biggs J (2014) Common processes at unique volcanoes - a volcanological conundrum. Front Earth Sci 2:28

Chesner CA, Halsor SP (1997) Geochemical trends of sequential lava flows from Meseta volcano, Guatemala. J Volcanol Geotherm Res 78:221-237. https://doi.org/10.1016/S0377-0273(97)00014-0

Chesner CA, Rose WI (1984) Geochemistry and evolution of the Fuego volcanic complex, Guatemala. J Volcanol Geotherm Res 21:25-44. https://doi.org/10.1016/0377-0273(84)90014-3

Cioni R, Santacroce R, Sbrana A (1999) Pyroclastic deposits as a guide for reconstructing the multi-stage evolution of the Somma-Vesuvius Caldera. Bull Volcanol 61:207-222

Clague DA, Dalrymple GB (1987) The Hawaiian-Emperor volcanic chain. part I. Geologic evolution. In: Decker RW, Wright TL, Stauffer PH (eds) Volcanism in Hawaii, US Geological Survey professional paper 1350, U.S. Government Printing Office, Washington, DC, pp. 5-54

Connor C, Bebbington M, Marzocchi W (2015) Probabilistic Volcanic Hazard Assessment. In: Sigurdsson H, Houghton B, McNutt S, Rymer H, Stix J (eds) The Encyclopedia of Volcanoes, 2nd edn. Academic Press, Cambridge, pp 897-910

Correale A, Paonita A, Martelli M et al (2014) A two-component mantle source feeding Mt. Etna magmatism: insights from the geochemistry of primitive magmas. Lithos 184:243-258

Corsaro RA, Métrich N (2016) Chemical heterogeneity of Mt. Etna magmas in the last $15 \mathrm{ka}$. Inferences on their mantle sources. Lithos 252:123-134

De la Cruz-Reyna S (1991) Poisson-distributed patterns of explosive eruptive activity. Bull Volcanol 54:57-67

De la Cruz-Reyna S (1993) Random patterns of occurrence of explosive eruptions at Colima Volcano, Mexico. J Volcanol Geotherm Res 55: 51-68

de Silva S, Lindsay JM (2015) Primary volcanic landforms. In: Sigurdsson H, Houghton B, McNutt S, Rymer H, Stix J (eds) The Encyclopedia of Volcanoes, 2nd edn. Academic Press, Cambridge, pp 273-297

Decker RW, Wright TL, Stauffer PH (1987) Volcanism in Hawaii, US Geological Survey professional paper 1350. U.S. Government Printing Office, Washington, DC

Deligne NI, Coles SG, Sparks RSJ (2010) Recurrence rates of large explosive volcanic eruptions. J Geophys Res Solid Earth 115(B6)

Diament M, Harjono H, Karta K, Deplus C, Dahrin D, Zen MT Jr et al (1992) Mentawai fault zone off Sumatra: a new key to the geodynamics of western Indonesia. Geology 20:259-262

Dvorak JJ (1992) Mechanism of explosive eruptions of Kilauea Volcano, Hawaii. Bull Volcanol 54:638-645

Easton RM (1987) Stratigraphy of Kilauea volcano. In: Decker RW, Wright TL, Stauffer PH (eds) Volcanism in Hawaii, US Geological 
Survey professional paper 1350. U.S. Government Printing Office, Washington, DC, pp 243-260

Euillades LD, Grosse P, Euillades PA (2013) NETVOLC: an algorithm for automatic delimitation of volcano edifice boundaries using DEMs. Comput Geosci 56:151-160. https://doi.org/10.1016/j. cageo.2013.03.011

Fiske RS, Rose TR, Swanson DA et al (2009) Kulanaokuaiki Tephra (ca. AD 400-1000): newly recognized evidence for highly explosive eruptions at Kīlauea Volcano, Hawai 'i. Geol Soc Am Bull 121: $712-728$

Furlan C (2010) Extreme value methods for modelling historical series of large volcanic magnitudes. Stat Model 10:113-132

Global Volcanism Program (2013) Volcanoes of the world, v. 4.6.7. Venzke, E (ed.). Smithsonian Institution. Downloaded 8 May 2018. https://doi.org/10.5479/si.GVP.VOTW4-2013

Grosse P, van Wyk de Vries B, Petrinovic IA et al (2009) Morphometry and evolution of arc volcanoes. Geology 37:651-654. https://doi. org/10.1130/G25734A.1

Grosse P, van Wyk de Vries B, Euillades PA et al (2012) Systematic morphometric characterization of volcanic edifices using digital elevation models. Geomorphology 136:114-131. https://doi.org/10. 1016/j.geomorph.2011.06.001

Grosse P, Euillades PA, Euillades LD, van Wyk de Vries B (2014) A global database of composite volcano morphometry. Bull Volcanol 76:1-16. https://doi.org/10.1007/s00445-013-0784-4

Gudmundsson MT, Jónsdóttir K, Hooper A et al (2016) Gradual caldera collapse at Bárdarbunga volcano, Iceland, regulated by lateral magma outflow. Science 353(6296):aaf8988

Gunawan H, Surono, Budianto A et al (2019) Overview of the eruptions of Sinabung eruption, 2010 and 2013-present and details of the 2013 phreatomagmatic phase. J Volcanol Geotherm Res. https:// doi.org/10.1016/j.jvolgeores.2017.08.005

Hincks TK, Komorowski J-C, Sparks SR, Aspinall WP (2014) Retrospective analysis of uncertain eruption precursors at La Soufrière volcano, Guadeloupe, 1975-77: volcanic hazard assessment using a Bayesian Belief Network approach. J Appl Volcanol 3: $1-26$

Hone DWE, Mahony SH, Sparks RSJ, Martin KT (2007) Cladistic analysis applied to the classification of volcanoes. Bull Volcanol 70: 203-220

Hutchison W, Mather TA, Pyle DM et al (2018) The evolution of magma during continental rifting: new constraints from the isotopic and trace element signatures of silicic magmas from Ethiopian volcanoes. Earth Planet Sci Lett 489:203-218

Jenkins S, Magill C, McAneney J, Blong R (2012) Regional ash fall hazard I: a probabilistic assessment methodology. Bull Volcanol 74:1699-1712

Le Bas MJ, Maitre RW, Streckeisen A et al (1986) A chemical classification of volcanic rocks based on the total alkali-silica diagram. J Petrol 27:745-750

Le Maitre RW, Streckeisen A, Zanettin B et al (2005) Igneous rocks: a classification and glossary of terms: recommendations of the International Union of Geological Sciences Subcommission on the Systematics of Igneous Rocks. Cambridge University Press, Cambridge

Loughlin SC, Vye-Brown C, Sparks RSJ et al (2015) An introduction to global volcanic hazard and risk. In: Loughlin SC, Sparks RSJ, Brown SK, Jenkins SF, Vye-Brown C (eds) Global volcanic hazards and risk. Cambridge University Press Cambridge, Cambridge, pp 180

Luhr JF, Carmichael ISE (1990) Petrological monitoring of cyclical eruptive activity at Volcan Colima, Mexico. J Volcanol Geotherm Res 42:235-260

Lyons JJ, Waite GP, Rose WI, Chigna G (2010) Patterns in open vent, strombolian behavior at Fuego volcano, Guatemala, 2005-2007. Bull Volcanol 72:1
Martin DP, Rose WI (1981) Behavioral patterns of Fuego volcano, Guatemala. J Volcanol Geotherm Res 10:67-81. https://doi.org/10. 1016/0377-0273(81)90055-X

Marzocchi W, Bebbington MS (2012) Probabilistic eruption forecasting at short and long time scales. Bull Volcanol 74:1777-1805

Marzocchi W, Jordan TH (2014) Testing for ontological errors in probabilistic forecasting models of natural systems. Proc Natl Acad Sci 111:11973-11978

Marzocchi W, Sandri L, Gasparini P, et al (2004) Quantifying probabilities of volcanic events: the example of volcanic hazard at Mount Vesuvius. J Geophys Res Solid Earth 109

Marzocchi W, Sandri L, Selva J (2008) BET_EF: a probabilistic tool for long-and short-term eruption forecasting. Bull Volcanol 70:623-632

Marzocchi W, Sandri L, Selva J (2010) BET_VH: a probabilistic tool for long-term volcanic hazard assessment. Bull Volcanol 72:705-716

Mastin LG, Christiansen RL, Thornber C et al (2004) What makes hydromagmatic eruptions violent? Some insights from the Keanakāko'i Ash, Kīlauea Volcano, Hawai'i. J Volcanol Geotherm Res 137:15-31. https://doi.org/10.1016/j.jvolgeores.2004.05.015

Mastin LG, Guffanti M, Servranckx R et al (2009) A multidisciplinary effort to assign realistic source parameters to models of volcanic ashcloud transport and dispersion during eruptions. J Volcanol Geotherm Res 186:10-21

Mastrandrea M, Field C, Stocker T, Edenhofer O, Ebi K, Frame D, Held H, Kriegler E, Mach K, Matschoss P et al (2010) Guidance note for lead authors of the IPCC fifth assessment report on consistent treatment of uncertainties. Intergovernmental Panel on Climate Change (IPCC), URL https://www.ipcc-wg1.unibe.ch/guidancepaper/ar5 uncertainty-guidance-note.pdf

MATLAB (2012) MATLAB release 2012B. Natick, MA, United States: The MathWorks, Inc

McPhie J, Walker GPL, Christiansen RL (1990) Phreatomagmatic and phreatic fall and surge deposits from explosions at Kilauea volcano, Hawaii, 1790 AD: Keanakakoi Ash Member. Bull Volcanol 52:334 354

Mead S, Magill C (2014) Determining change points in data completeness for the Holocene eruption record. Bull Volcanol 76:874

Naismith AK, Watson IM, Escobar-Wolf R et al (2019) Eruption frequency patterns through time for the current (1999-2018) activity cycle at Volcán de Fuego derived from remote sensing data: evidence for an accelerating cycle of explosive paroxysms and potential implications of eruptive activity. J Volcanol Geotherm Res 371:206-219

Nakada S, Zaennudin A, Yoshimoto M et al (2019) Growth process of the lava dome/flow complex at Sinabung Volcano during 2013-2016. J Volcanol Geotherm Res. https://doi.org/10.1016/j.jvolgeores.2017. 06.012

Newhall C, Hoblitt R (2002) Constructing event trees for volcanic crises. Bull Volcanol 64:3-20

Neal CA, Brantley SR, Antolik L, Babb JL, Burgess M, Calles K, Cappos M, Chang JC, Conway S, Desmither L, Dotray P, Elias T, Fukunaga P, Fuke S, Johanson IA, Kamibayashi K, Kauahikaua J, Lee RL, Pekalib S, Miklius A, Million W, Moniz CJ, Nadeau PA, Okubo P, Parcheta C, Patrick MR, Shiro B, Swanson DA, Tollett W, Trusdell F, Younger EF, Zoeller MH, Montgomery-Brown EK, Anderson KR, Poland MP, Ball JL, Bard J, Coombs M, Dietterich HR, Kern C, Thelen WA, Cervelli PF, Orr T, Houghton BF, Gansecki C, Hazlett R, Lundgren P, Diefenbach AK, Lerner AH, Waite G, Kelly P, Clor L, Werner C, Mulliken K, Fisher G, Damby D (2019) The 2018 rift eruption and summit collapse of Kîlauea Volcano. Science 363 (6425):367-374

Newhall CG, Pallister JS (2015) Using multiple data sets to populate probabilistic volcanic event trees. In: Papale P (ed) Volcanic hazards, risks, and disasters. Elsevier, Amsterdam, pp 203-232

Newhall CG, Punongbayan RS (1996) Fire and mud: eruptions and lahars of Mount Pinatubo, Philippines. PHIVOLCS, Quezon City, and University of Washington Press, Seattle 
Newhall CG, Self S (1982) The volcanic explosivity index (VEI) an estimate of explosive magnitude for historical volcanism. J Geophys Res-Oceans 87:1231-1238

Newhall CG, Costa F, Ratdomopurbo A et al (2017) WOVOdat-an online, growing library of worldwide volcanic unrest. J Volcanol Geotherm Res 345:184-199

Ogburn SE, Loughlin SC, Calder ES (2015) The association of lava dome growth with major explosive activity $(\mathrm{VEI} \geq 4)$ : DomeHaz, a global dataset. Bull Volcanol 77:40

Ogburn SE, Berger J, Calder ES et al (2016) Pooling strength amongst limited datasets using hierarchical Bayesian analysis, with application to pyroclastic density current mobility metrics. Stat Volcanol 2:1

Ort MH, Di Muro A, Michon L, Bachèlery P (2016) Explosive eruptions from the interaction of magmatic and hydrothermal systems during flank extension: the Bellecombe Tephra of Piton de La Fournaise (La Réunion Island). Bull Volcanol 78(1):5

Pallister J, Wessels R, Griswold J, McCausland W, Kartadinata N, Gunawan H, Budianto A, Primulyana S (2019) Monitoring, forecasting collapse events, and mapping pyroclastic deposits at Sinabung volcano with satellite imagery. J Volcanol Geotherm Res 382:149-163

Pearce JA (1996) A user's guide to basalt discrimination diagrams. In: Wyman DA (ed) Trace element geochemistry of volcanic rocks: applications for massive sulphide exploration. Geol Assoc Canada, Short Course Notes 12:79-113

Peltier A, Poland M, Staudacher T (2015) Are Piton de la Fournaise (La Réunion) and Kîlauea (Hawai'i) really "analog volcanoes". In: Carey R, Cayol V, Poland M, Weis D (eds) Hawaiian Volcanoes: From Source to Surface, Geophys Monogr Ser 208. John Wiley \& Sons, Hoboken, pp 507-531

Perfit MR, Davidson JP (2000) Plate tectonics and volcanism. In: Sigurdsson H, Houghton BF, McNutt SR, Rymer H, Stix J (eds) Encyclopedia of Volcanoes, 1st edn. Academic Press, Cambridge, pp 89-113

Pike RJ (1978) Volcanoes on the inner planets-Some preliminary comparisons of gross topography. In: Lunar and Planetary Science Conference Proceedings. pp 3239-3273

Pike RJ, Clow GD (1981) Revised classification of terrestrial volcanoes and catalog of topographic dimensions, with new results of edifice volume, USGS Open File Report 81-1038

Poland MP, Peltier A, Bonforte A, Puglisi G (2017) The spectrum of persistent volcanic flank instability: a review and proposed framework based on Kīlauea, Piton de la Fournaise, and Etna. J Volcanol Geotherm Res 339:63-80. https://doi.org/10.1016/j.jvolgeores. 2017.05.004

Quane SL, Garcia MO, Guillou H, Hulsebosch TP (2000) Magmatic history of the East Rift Zone of Kilauea Volcano, Hawaii based on drill core from SOH 1. J Volcanol Geotherm Res 102:319-338

Rodado A, Bebbington M, Noble A et al (2011) On selection of analog volcanoes. Math Geosci 43:505-519

Rogers N (2015) The composition and origin of magmas. In: Sigurdsson H, Houghton B, McNutt S, Rymer H, Stix J (eds) The encyclopedia of volcanoes, 2nd edn. Academic Press, Cambridge, pp 93-112

Rose WI, Anderson AT, Woodruff LG, Bonis SB (1978) The October 1974 basaltic tephra from Fuego volcano: description and history of the magma body. J Volcanol Geotherm Res 4:3-53. https://doi.org/ 10.1016/0377-0273(78)90027-6

Rosi M, Bertagnini A, Landi P (2000) Onset of the persistent activity at Stromboli volcano (Italy). Bull Volcanol 62:294-300

Rougier J, Sparks SR, Cashman KV (2016) Global recording rates for large eruptions. J Appl Volcanol 5:11

Sandri L, Jolly G, Lindsay J et al (2012) Combining long-and short-term probabilistic volcanic hazard assessment with cost-benefit analysis to support decision making in a volcanic crisis from the Auckland Volcanic Field, New Zealand. Bull Volcanol 74:705-723

Sandri L, Thouret J-C, Constantinescu R et al (2014) Long-term multihazard assessment for El Misti volcano (Peru). Bull Volcanol 76:126

Selva J, Marzocchi W, Papale P, Sandri L (2012) Operational eruption forecasting at high-risk volcanoes: the case of Campi Flegrei, Naples. J Appl Volcanol 1:5

Sheldrake T (2014) Long-term forecasting of eruption hazards: a hierarchical approach to merge analogous eruptive histories. J Volcanol Geotherm Res 286:15-23. https://doi.org/10.1016/j.jvolgeores. 2014.08.021

Siebert L, Simkin T, Kimberly P (2010) Volcanoes of the world. Univ of California Press, Berkeley

Sigurdsson H, Houghton B, McNutt S et al (2015) The encyclopedia of volcanoes, 1 st edn. Elsevier, Amsterdam

Sobradelo R, Geyer A, Martí J (2010) Statistical data analysis of the CCDB (Collapse Caldera Database): insights on the formation of caldera systems. J Volcanol Geotherm Res 198:241-252

Spiller ET, Bayarri MJ, Berger JO et al (2014) Automating emulator construction for geophysical hazard maps. SIAM/ASA J Uncertain Quantif 2:126-152

Swanson DA, Houghton BF (2018) Products, processes, and implications of Keanakāko'i volcanism, Kīlauea Volcano, Hawai 'i. In: Poland MP, Garcia MO, Camp VE, Grunder A (eds) Field volcanology: a tribute to disting career Don Swanson, Geol Soc Am Spec Pap 538, Boulder, CO, pp. 159-190

Swanson DA, Rose TR, Mucek AE et al (2014) Cycles of explosive and effusive eruptions at Kīlauea Volcano, Hawai'i. Geology 42:631634. https://doi.org/10.1130/G35701.1

Taddeucci J, Edmonds M, Houghton B et al (2015) Hawaiian and Strombolian eruptions. In: Sigurdsson H, Houghton B, McNutt S, Rymer H, Stix J (eds) The encyclopedia of volcanoes, 2nd edn. Academic Press, Cambridge, pp 485-503

Thouret J-C, Oehler J-F, Gupta A et al (2014) Erosion and aggradation on persistently active volcanoes - a case study from Semeru Volcano, Indonesia. Bull Volcanol 76:857

Tierz P, Sandri L, Costa A, Zaccarelli L, di Vito MA, Sulpizio R, Marzocchi W (2016a) Suitability of energy cone for probabilistic volcanic hazard assessment: validation tests at Somma-Vesuvius and Campi Flegrei (Italy). Bull Volcanol 78:1-15. https://doi.org/10. 1007/s00445-016-1073-9

Tierz P, Sandri L, Costa A et al (2016b) Uncertainty assessment of pyroclastic density currents at Mount Vesuvius (Italy) simulated through the energy cone model. In: Webley P, Riley K, Thompson MP (eds) Natural hazard uncertainty assessment: modeling and decision support, Geophys Monogr Ser 208. John Wiley \& Sons, Hoboken, pp 125-145

Tierz P, Woodhouse MJ, Phillips JC, et al (2017) A framework for probabilistic multi-hazard assessment of rain-triggered lahars using Bayesian belief networks. Front Earth Sci 5. doi: https://doi.org/ 10.3389/feart.2017.00073

Whelley PL, Newhall CG, Bradley KE (2015) The frequency of explosive volcanic eruptions in Southeast Asia. Bull Volcanol 77:1

Wright HMN, Pallister JS, McCausland WA et al (2019) Construction of probabilistic event trees for eruption forecasting at Sinabung volcano, Indonesia 2013-14. J Volcanol Geotherm Res. https://doi.org/ 10.1016/j.jvolgeores.2018.02.003

Zobin VM, Luhr JF, Taran YA et al (2002) Overview of the 1997-2000 activity of Volcán de Colima, Mexico. J Volcanol Geotherm Res 117:1-19 